\title{
Celecoxib Ameliorates Seizure Susceptibility in Autosomal Dominant Lateral Temporal Epilepsy
}

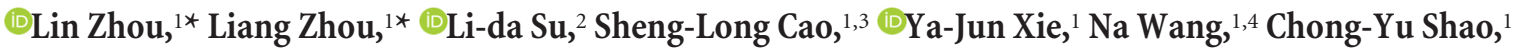 \\ Ya-Nan Wang, ${ }^{1}$ Jia-Huan Zhou, ${ }^{1}$ John K. Cowell, ${ }^{1,5}$ and Ying Shen ${ }^{1}$ \\ ${ }^{1}$ Department of Neurobiology, Key Laboratory of Medical Neurobiology of Zhejiang Province, Zhejiang University School of Medicine, Hangzhou 310058, \\ China, ${ }^{2}$ Neuroscience Care Unit, ${ }^{3}$ Department of Neurosurgery, Second Affiliated Hospital of Zhejiang University School of Medicine, Hangzhou 310009, \\ China, ${ }^{4}$ School of Medicine, Zhejiang University City College, Hangzhou 310015, China, and ${ }^{5}$ GRU Cancer Center, Augusta University, Augusta, Georgia \\ 30912
}

Autosomal dominant lateral temporal epilepsy (ADLTE) is an inherited syndrome caused by mutations in the leucine-rich glioma inactivated 1 (LGI1) gene. It is known that glutamatergic transmission is altered in LGI1 mutant mice, and seizures can be reduced by restoring LGIl function. Yet, the mechanism underlying ADLTE is unclear. Here, we propose that seizures in male $\mathrm{LGII}^{-1-}$ mice are due to nonsynaptic epileptiform activity in cortical neurons. We examined the intrinsic excitability of pyramidal neurons in the temporal cortex of male $L G I 1^{-1-}$ mice and found that the voltage-gated $\mathrm{K}^{+}$channel Kv1.2 was significantly downregulated. We also found that cytosolic phospholipase $\mathrm{A}_{2}\left(\mathrm{CPLA}_{2}\right)$-cyclooxygenase 2 (Cox2) signaling was enhanced in $L G I 1^{-1-}$ mice. Interestingly, Cox2 inhibition effectively restored the dysregulated Kv1.2 and reduced the intrinsic excitability of pyramidal neurons. Moreover, in vivo injection of celecoxib, an FDA-approved nonsteroidal anti-inflammatory drug, rescued the defective Kv1.2 (an $\sim 1.9$-fold increase), thereby alleviating the seizure susceptibility and extending the life of $\mathrm{LGII}^{-/-}$mice by $5 \mathrm{~d}$. In summary, we conclude that LGI1 deficiency dysregulates ${ }_{\mathrm{CPLA}}$-Cox2 signaling to cause hyperexcitability of cortical pyramidal neurons, and celecoxib is a potential agent to manage human ADLTE.

Key words: ADLTE; celecoxib; Cox2; epilepsy; Kv1.2

Significance Statement

Haploinsufficiency of the leucine-rich glioma inactivated 1 (LGI1) gene is the major pathogenic basis for ADLTE, an inherited syndrome with no cure to date. Existing studies suggest that altered glutamatergic transmission in the hippocampus causes this disease, but the data are paradoxical. We demonstrate that the loss of LGI1 decreases Kv1.2 expression, enhances intrinsic excitability, and thereby causes epilepsy. Interestingly, for the first time, we show that an FDA-approved drug, celecoxib, rescues the Kv1.2 defect and alleviates seizure susceptibility in $\mathrm{LGI1}^{-1-}$ mice, as well as improving their survival. Thus, we suggest that celecoxib is a promising drug for the treatment of ADLTE patients.

\section{Introduction}

Autosomal dominant lateral temporal epilepsy (ADLTE, also known as autosomal dominant epilepsy with auditory features) is

\footnotetext{
Received Nov. 14, 2017; revised Jan. 24, 2018; accepted Feb. 20, 2018.

Author contributions: Lin Zhou and Y.S. designed research; Lin Zhou, Liang Zhou, L.-d.S., S.-L.C., Y.-J.X., N.W., C.-Y.S., Y.-N.W., and J.-H.Z. performed research; J.K.C. contributed unpublished reagents/analytic tools; Lin Zhou, Liang Zhou, N.W., and Y.S. analyzed data; Lin Zhou, J.K.C., and Y.S. wrote the paper.

This work was supported by National Natural Science Foundation of China Grants 81625006, 31471024, and 31571051, and Natural Science Foundation of Zhejiang Province Grant Z15C090001. The generation of LGI1-null mice was supported by National Institutes of Health Grant CA046706 to J.K.C. We thank Dr. Z. Josh Huang (Cold Spring Harbor Laboratory, New York) for providing the G42 mutant mice, the Core Facilities of Zhejiang University Institute of Neuroscience for technical assistance, Dr. Zhouyan Feng (Zhejiang University School of Biomedical Engineering, Hangzhou, (hina) for the suggestions in statistics, and Dr. lain C. Bruce for reading the manuscript. The authors declare no competing financial interests.

*Lin Zhou and Liang Zhou contributed equally to this work.
}

an inherited syndrome characterized by the onset of temporal cortical seizures in adolescence or early adulthood (Ottman et al., 1995 ) in the absence of structural abnormalities by MRI (Michelucci et al., 2003). ADLTE seizures occur at a low frequency (1-2 per month) and usually during sleep (Michelucci et al., 2003, 2007). Aphasia and visual hallucinations are reported in a minority of patients, either alone or accompanying auditory symptoms (Michelucci et al., 2003, 2007). Haploinsufficiency of the leucine-rich glioma-inactivated 1 (LGI1) gene is the major pathogenic basis for human ADLTE (Kalachikov et al., 2002; Senechal et al., 2005;

Correspondence should be addressed to Dr. Ying Shen, 866 Yu Hang Tang Road, Hangzhou 310058, China. E-mail: yshen@zju.edu.cn.

DOI:10.1523/JNEUROSCI.3245-17.2018

Copyright $\odot 2018$ the authors $\quad 0270-6474 / 18 / 383346-12 \$ 15.00 / 0$ 
Fukata et al., 2006). Homozygous $L G I 1^{-1-}$ mice display generalized seizures and premature death (Chabrol et al., 2010; Fukata et al., 2010; Yu et al., 2010), whereas heterozygous $L G I 1^{+1-}$ mice display increased seizure susceptibility to acoustic stimuli (Chabrol et al., 2010) and the convulsant agent pentylenetetrazole (PTZ) (Fukata et al., 2010).

Several functions of LGI1 in the CNS have been demonstrated: (1) inhibiting the inactivation of the presynaptic $\mathrm{K}^{+}$channel Kv1 (Schulte et al., 2006); (2) regulating the pruning of glutamatergic synapses in the hippocampus (Zhou et al., 2009) through interaction with ADAM (a disintegrin and metalloproteinase) (Fukata et al., 2006, 2010; Ohkawa et al., 2013); (3) increasing neuronal growth through an interaction with Nogo receptors (Thomas et al., 2010); and (4) causing subtle cortical dyslamination (Silva et al., 2015) and reduced thickness of the external granule layer with abnormal foliation in the embryonic cerebellum (Xie et al., 2015). Using conditional lines, Boillot et al. (2014) demonstrated that glutamatergic neurons contribute to the seizure phenotypes in $L G I 1^{-1-}$ mice. Similarly, two independent studies have suggested that altered glutamatergic transmission is the pathologic basis for the seizure phenotypes in $\mathrm{LGI1}^{-1-}$ mice (Fukata et al., 2010; Yu et al., 2010).

However, how LGI1 deficiency leads to seizures remains unclear. In $L G I 1^{-1-}$ mice, Yu et al. (2010) showed enhanced glutamate transmission in the hippocampus, but Fukata et al. (2010) suggested that it is reduced. While this discrepancy may be due to knock-out strategies, it is possible that hippocampal synaptic transmission is not the decisive factor in ADLTE. Indeed, increased epileptic discharges are evident characteristics of ADLTE patients with LGI1 mutations (Ottman et al., 1995; Michelucci et al., 2009). Here, we set out to investigate the intrinsic excitability of pyramidal neurons in the temporal lobe cortex of $L G I 1^{-1-}$ mice and the effects of celecoxib.

\section{Materials and Methods}

Animals. The animal experiments were approved by the Animal Experimentation Ethics Committee of Zhejiang University. Wild-type (WT) and $L G I 1^{-1-}$ mice were maintained at the Experimental Animal Center of Zhejiang University and kept in temperature-controlled conditions under a 12:12 h light/dark cycle with food and water ad libitum. Male mice were used in all experiments.

Antibodies and reagents. Antibodies against Kv1.2 (\#K14/16), Kv1.4 (\#K13/31), Kv1.6 (\#K19/36), Nav1.1 (\#K74/71), Nav1.2 (\#K69/3), and Nav1.6 (\#K87a/10) were from NeuroMab. Antibodies against PSD95 (\#MAB1596), synaptophysin (\#MAB368), and GAPDH (\#MAB374) were from Millipore. TsT $\alpha$, atropine, and antibodies against LGI1 (\#ab30868) and Cox2 (\#ab15191) were from Abcam. Antibodies against Cox1 (\#sc1754), 12-lipoxygenase (\#sc-32939), and 15-lipoxygenase (\#sc-133085) were from Santa Cruz Biotechnology. Antibodies against 5-lipoxygenase (\#3289), cPLA 2 (\#5249), and pcPLA 2 (\#2831s) were from Cell Signaling Technology. HRP-conjugated secondary antibody was from GE Healthcare. Antirabbit and antimouse secondary antibodies for Western blots were from Thermo Scientific. AlexaFluor-conjugated secondary antibodies were from Invitrogen. The protease inhibitor was from Merck Chemicals. Other reagents were from Sigma-Aldrich unless stated otherwise.

PTZ-induced seizures and scoring. Seizures were measured in $35 \mathrm{~d}$-old (P35) mice injected with PTZ at $45 \mathrm{mg} / \mathrm{kg}$ (i.p.). The behavior and seizure activity were observed and scored by investigators who were blinded to the genotype throughout the experiments. Seizures were scored for 30 min after injection as follows (Ferraro et al., 1999): 1, hypoactivity (abdomen in full contact with the bottom of the cage in the resting position); 2 , focal clonus (of face, head, or forelimbs); 3 , generalized clonus (rearing, falling, and clonus of four limbs and tail); 4, clonic (tonic seizure, tonic hindlimb extension, or death).
Animal surgery. On P12 (9-10 g) and P28 (18-20 g), mice were deeply anesthetized with pentobarbital $(30 \mathrm{mg} / \mathrm{kg})$ and placed in a stereotaxic apparatus (Stoelting). EEG recording electrodes (\#795500, A. M. Systems), which were made of twisted stainless-steel wire (diameter: 0.125 $\mathrm{mm}$ ) fully insulated with Teflon, except for $0.5 \mathrm{~mm}$ at the tip, were implanted into the motor cortex (bregma: anteroposterior, $-2.0 \mathrm{~mm}$; mediolateral, $\pm 2.0 \mathrm{~mm}$; dorsoventral, $-1.5 \mathrm{~mm}$ ) according to the mouse atlas (Franklin and Paxinos, 2001). Two screws were placed in the skull over the cerebellum to serve as the reference and ground electrodes and to secure the dental cement (Wang et al., 2017). The maximal tip separation between recording and reference electrodes was $0.5 \mathrm{~mm}$. Electrode locations were histologically verified after the behavioral studies.

EEG recording. After complete recovery from surgery, the implanted animals were placed in a round transparent cage and allowed to move freely. A recording system was connected to the mice (Chabrol et al., 2010); then the EEGs were bandpass filtered spanning DC to $200 \mathrm{~Hz}$ and sampled at $2 \mathrm{kHz}$ using an amplifier (Neuroscan System). EEG recordings were limited to $4-5 \mathrm{~h}$ per day and repeated daily until the death of each mouse. For PTZ-induced seizures, EEG recordings were continued for 30 min after PTZ injection.

Primary neuronal culture. Primary neuronal cultures were made according to previous work (Wang et al., 2015). In brief, cortices were dissected from embryonic mice (E16). Dissociated neurons were plated and cultured in Neurobasal medium supplemented with $2 \%$ B-27 and $2 \mathrm{~mm}$ L-alanyl-glutamine (NM). At $48 \mathrm{~h}$ after plating, the primary cultures were treated with $2.5 \mu \mathrm{M}$ cytosine arabinoside for $24 \mathrm{~h}$ and the medium was replaced with fresh NM. Cultures were maintained at $37^{\circ} \mathrm{C}$ in a humidified incubator gassed with $95 \% \mathrm{O}_{2}$ and $5 \% \mathrm{CO}_{2}$. The medium was renewed every $3 \mathrm{~d}$.

Isolation of synaptic fraction. Brain tissues were homogenized in SHEEP buffer (in mM as follows: 380 sucrose, 4 HEPES, pH 7.5, 0.1 EDTA, and 0.1 EGTA) supplemented with protease inhibitors (Merck Chemicals) and centrifuged at $800 \times g\left(4^{\circ} \mathrm{C}\right.$ for $\left.15 \mathrm{~min}\right)$. The supernatant was then centrifuged at $9200 \times g\left(4^{\circ} \mathrm{C}\right.$ for $\left.15 \mathrm{~min}\right)$. The pellet $(\mathrm{P} 2)$ provided the crude synaptic fraction (Fukata et al., 2010).

Western blotting. Samples (temporal cortical tissues or cortical cultures) were rinsed with PBS and diluted in 1\% SDS containing protease inhibitor mixture. After determining the protein concentration using the BCA protein assay (Bio-Rad), equal quantities of proteins were loaded and fractionated on SDS-PAGE gels, transferred to PVDF membranes (Immobilon-P, Millipore), immunoblotted with antibodies, and visualized by enhanced chemiluminescence (Pierce Biotechnology). The primary antibody dilutions were 1:1000 for LGI1; 1:500 for Cox2, Cox1, 5-, 12-, and 15-lipoxygenase, $\mathrm{cPLA}_{2}$, $\mathrm{pcPLA}_{2}$, and Kv1.2; 1:200 for Kv1.4, Kv1.6, Nav1.1, Nav1.2, and Nav1.6; and 1:10,000 for PSD95, synaptophysin, and GAPDH. The secondary antibodies were antirabbit (1: $10,000)$ and antimouse $(1: 10,000)$. Film signals were digitally scanned and protein levels were quantified by measuring the integrated optical densities of the bands after background subtraction using ImageJ, version 1.42q (National Institutes of Health) according to our previous work (Wang et al., 2015; Xie et al., 2015; Zhou et al., 2015, 2017). GAPDH immunoreactivity was set as the loading control in each experiment, and all data were normalized to corresponding GAPDH.

Immunohistochemistry. Sagittal cortical sections $(30 \mu \mathrm{m})$ were prepared and placed in blocking solution (1\% BSA, $0.3 \%$ Triton, $10 \%$ normal goat serum) for $1 \mathrm{~h}$ at room temperature. After washing with PBS, the sections were incubated with primary antibodies overnight at $4^{\circ} \mathrm{C}$ and then with secondary antibody for $1 \mathrm{~h}$ at room temperature. The sections were then mounted using ProLong Gold Antifade Reagent with DAPI (Invitrogen). The primary antibody dilution was 1:200 for Cox2. AlexaFluor 488-conjugated goat antirabbit IgG was diluted at 1:1000. All antibodies were diluted in PBS containing $1 \%$ BSA and $1 \%$ normal goat serum.

RNA preparation and real-time PCR. mRNA levels were assessed by real-time PCR using an ABI PRISM 7500 sequence detection system (Applied Biosystems). cDNA was synthesized by reverse transcription using oligo (dT) as the primer and proceeded to real-time PCR with gene-specific primers in the presence of SYBR Premix Ex Taq (DRR041A, Takara Biotechnology). Quantification was determined by the comparative cycle 
A
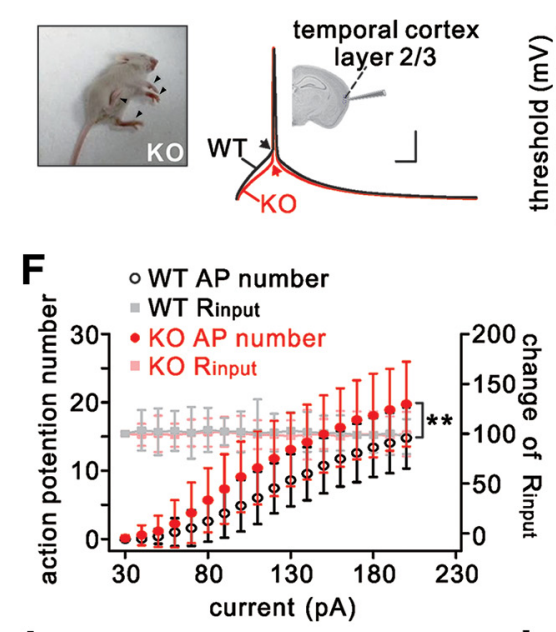

I

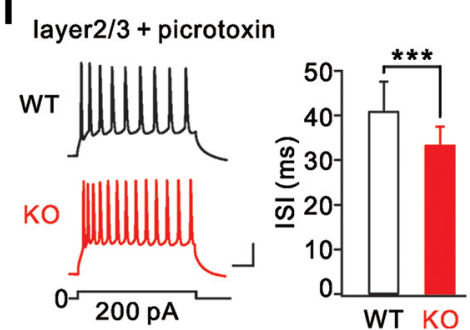

C

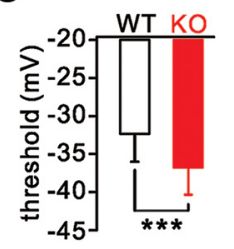

G
D

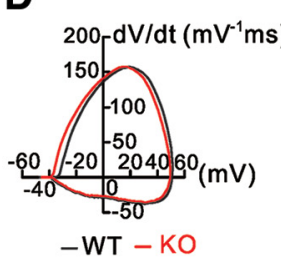

E ayer $2 / 3$

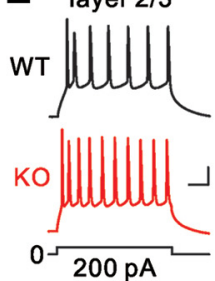

H interneuron
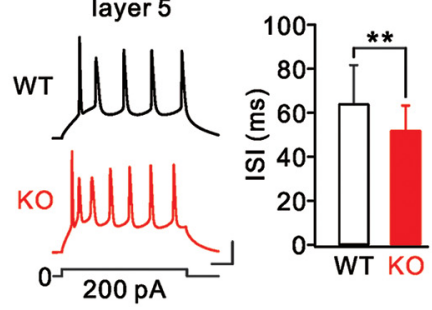

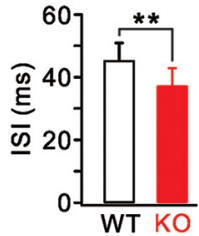

WT KO
$\mathrm{J}$

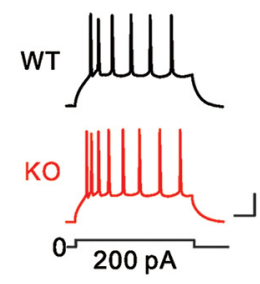

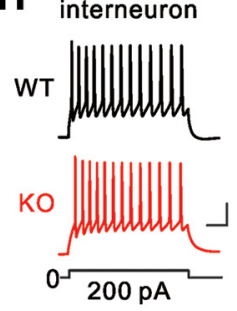

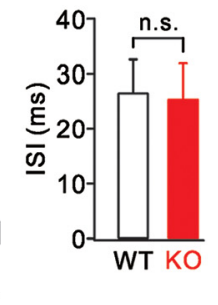

$\mathbf{K}$

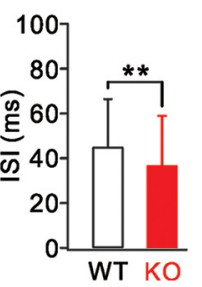

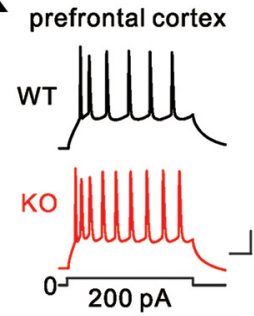

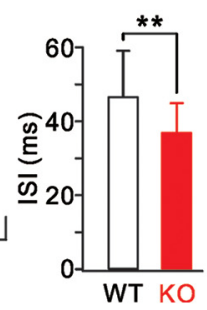

Figure 1. Hyperexcitability in temporal cortical pyramidal neurons from $\mathrm{LGI}^{-1-}$ (KO) mice. $A$, Arrowheads indicate tonic limb extension after spontaneous generalized seizures in a K0 mouse (P16). B, Action potentials induced by injecting a depolarizing current $(50 \mathrm{~ms})$ in WT and KO pyramidal neurons. Arrows indicate initiation of action potentials. Inset, Location of recordings in the temporal cortex. C, Summary of voltage thresholds (WT: $-32.3 \pm 3.8 \mathrm{mV}, n=23 ; \mathrm{KO}:-36.7 \pm 3.4 \mathrm{mV}, n=25)$. D, Phase-plane plots $\left(V_{\mathrm{m}}\right.$ vs $\mathrm{dV} / \mathrm{dt}$ ) for single action potentials induced in WT and $K 0$ neurons. The voltage threshold for the action potential in the KO neuron shifted to a more hyperpolarized level. $E$, Sample spikes from WT and KO neurons in response to a $300 \mathrm{~ms}$ current injection (200 pA) and summary of ISIs. $\boldsymbol{F}$, Input- output curves for WT $(n=34)$ and KO $(n=22)$ neurons showing numbers of action potentials as a function of injected currents lasting $800 \mathrm{~ms}$. Input resistances $\left(R_{\text {input }}\right)$ were monitored during the course of experiments. All $R_{\text {input }}$ values were normalized to the first point, and the percentages changes are on the $y$ axis on the right. $G$, Spikes of WT and KO layer 5 neurons in response to current injection. $\boldsymbol{H}$, Spikes and ISIs in WT and KO parvalbumin-positive interneurons. $I$, Spikes in WT and KO layer $2 / 3$ neurons treated with picrotoxin $(100 \mu \mathrm{M}) . J$, Spikes and ISIs in WT and KO layer 2/3 neurons treated with mecamylamine (MEC; $10 \mu \mathrm{M}$ ) and atropine (1 $\mu \mathrm{M}) . \boldsymbol{K}$, Spikes and ISIs in WT and K0 prefrontal cortex. Calibration: $20 \mathrm{mV}, 50$ ms. ${ }^{* *} p<0.01,{ }^{* * *} p<0.001$.

threshold $\left(\mathrm{C}_{\mathrm{t}}\right)$ method, using GAPDH as the internal control. The following forward $(\mathrm{F})$ and reverse $(\mathrm{R})$ primers were used to amplify: Cox2-F, 5'-GTG CTG ACA TCC AGA TC-3', Cox2-R, 5'-GAG TTG GGC AGT CAT CTG C-3'; GAPDH-F, 5' -TGT TAC CAA CTG GGA CGA CA-3', GAPDH-R, 5' -AAG GAA GGC TGG AAA AGA GC-3'.

Cox2 activity assay. Cox2 activity was assayed according to the manufacturer's instructions (Cayman Chemical). Temporal cortical tissues were homogenized in $2 \mathrm{ml} / \mathrm{g}$ tissue cold buffer ( $0.1 \mathrm{M}$ Tris-HCl, $\mathrm{pH} 7.8$; containing $1 \mathrm{~mm}$ EDTA), and centrifuged at $10,000 \times g$ for $15 \mathrm{~min}$ at $4^{\circ} \mathrm{C}$. The supernatant was then used for activity assays following the manufacturer's instructions, and the absorbance at $590 \mathrm{~nm}$ was read using a plate reader.

Slice preparation. Coronal slices of temporal or prefrontal cortex (300 $\mu \mathrm{m}$ ) from P14-P17 mice were cut in ice-cold aCSF (in mM as follows: 125 $\mathrm{NaCl}, 3 \mathrm{KCl}, 1.25 \mathrm{NaH}_{2} \mathrm{PO}_{4}, 2 \mathrm{MgSO}_{4}, 2 \mathrm{CaCl}_{2}, 25 \mathrm{NaHCO}_{3}, 10$ glucose) on a vibrating tissue slicer (VT 1000S, Leica). After recovery for $30 \mathrm{~min}$ at $37^{\circ} \mathrm{C}$, the slices were incubated at room temperature for $60 \mathrm{~min}$ and then transferred to the recording chamber and superfused (at $2 \mathrm{ml} / \mathrm{min}$ ) with aCSF at room temperature. All solutions were saturated with $95 \% \mathrm{O}_{2} / 5 \%$ $\mathrm{CO}_{2}$.

Electrophysiology. Neurons were visualized under an upright microscope (BX51, Olympus) with a $40 \times$ water-immersion objective and equipped with infrared differential interference contrast enhancement. Whole-cell recordings were obtained with an Axon MultiClamp 700B amplifier (Molecular Devices). Glass pipettes $(3-5 \mathrm{M} \Omega$ ) were filled with a solution containing the following (in $\mathrm{mM}$ ): $120 \mathrm{~K}$-gluconate, $20 \mathrm{KCl}, 10$ HEPES, $2 \mathrm{MgCl}_{2}$, 10 Na-phosphocreatine, 4 Mg-ATP, 0.3 Na-GTP, 0.1 EGTA (pH 7.3 with $\mathrm{KOH}, 290 \mathrm{mOsm}$ ). Currents were filtered at $2 \mathrm{kHz}$
Table 1. Electrophysiological properties of $L 2 / 3$ pyramidal neurons

\begin{tabular}{lcc}
\hline Parameter & WT (P14-P17) & K0 (P14-P17) \\
\hline ISI (ms) & $45.3 \pm 5.6$ & $37.2 \pm 5 . .^{* * *}$ \\
Rheobase (pA) & $83 \pm 18.8$ & $70 \pm 24.5^{* * *}$ \\
RMP (mV) & $-66 \pm 4.7$ & $-65 \pm 4.9$ \\
Input resistance (m $\Omega)$ & $151 \pm 18.8$ & $157 \pm 19.6$ \\
Amplitude (mV) & $108 \pm 9.4$ & $110 \pm 14.7$ \\
Half-width (ms) & $3.1 \pm 0.5$ & $3.0 \pm 0.5$ \\
No. of cells (mice) & $23(10)$ & $25(11)$ \\
\hline
\end{tabular}

${ }^{* * *} p<0.001 . \mathrm{K}^{\mathrm{L}} \mathrm{Lgi1}^{-1-}$

and digitized at $10 \mathrm{kHz}$. Recordings were excluded from analysis if series resistance, input resistance, or holding current varied by $\geq 15 \%$ over the course of an experiment. All electrophysiological experiments were performed at room temperature.

Pyramidal neurons were identified by their prominent apical dendrites and adaptive firing. G42 mutant mice (Li et al., 2011) that express enhanced green fluorescent protein in parvalbumin interneurons were crossed with $L G I 1^{+/-}$mice when interneuron recordings were required. The measurement of action potential and $\mathrm{K}^{+}$currents was as described previously (Dodson et al., 2002; Wen et al., 2010; Li et al., 2011; Gasselin et al., 2015). Passive neuronal properties were measured from single action potentials. The voltage threshold was defined as $\mathrm{d} V / \mathrm{d} t=10 \mathrm{mV} /$ $\mathrm{ms}$. The threshold voltage for an action potential (rheobase) was defined as the minimum depolarizing current needed to elicit an action potential, and measured just before action potential initiation. Spike amplitude was measured as the voltage difference between the peak and resting potential 
Table 2. Electrophysiological properties of neurons in mice at P14-P17

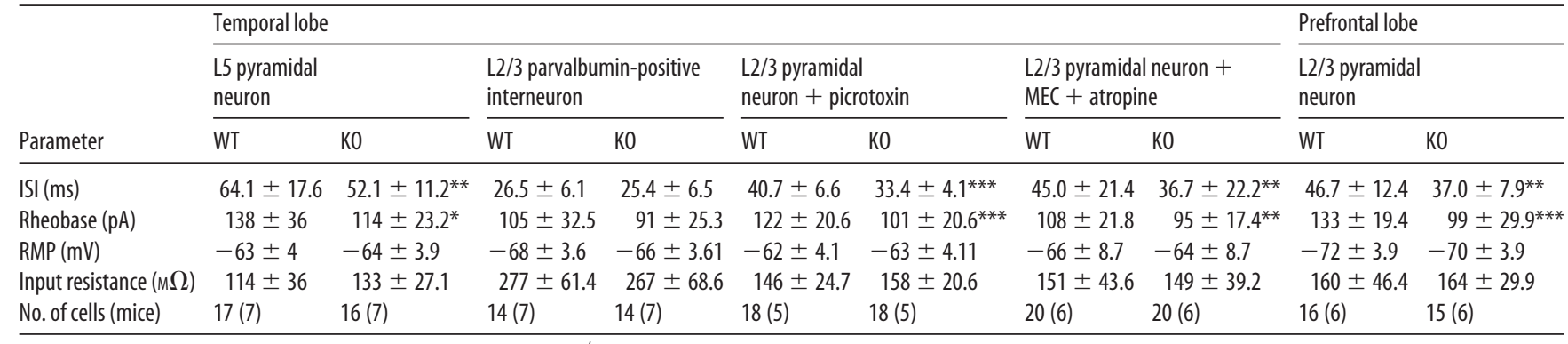

${ }^{*} p<0.05,{ }^{* *} p<0.01,{ }^{* * *} p<0.001$, compared with corresponding WT. K0: Lgi1 ${ }^{-1}$

A
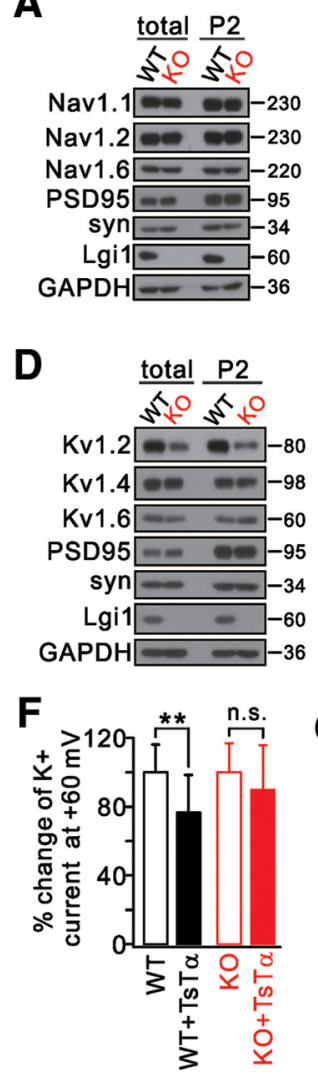
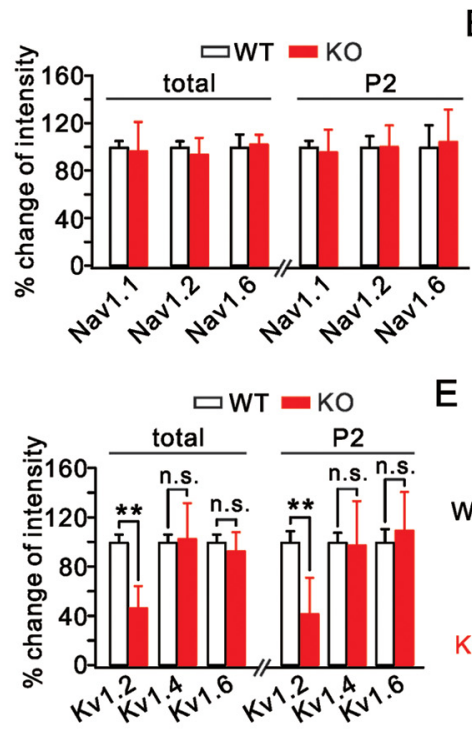

G

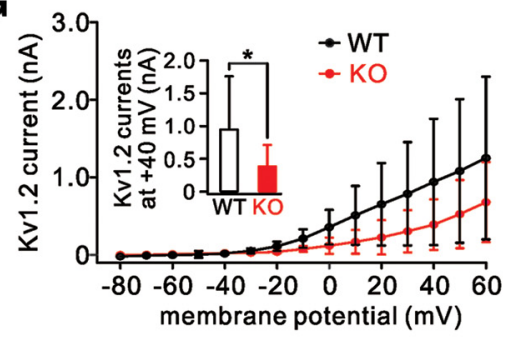

B

$E$
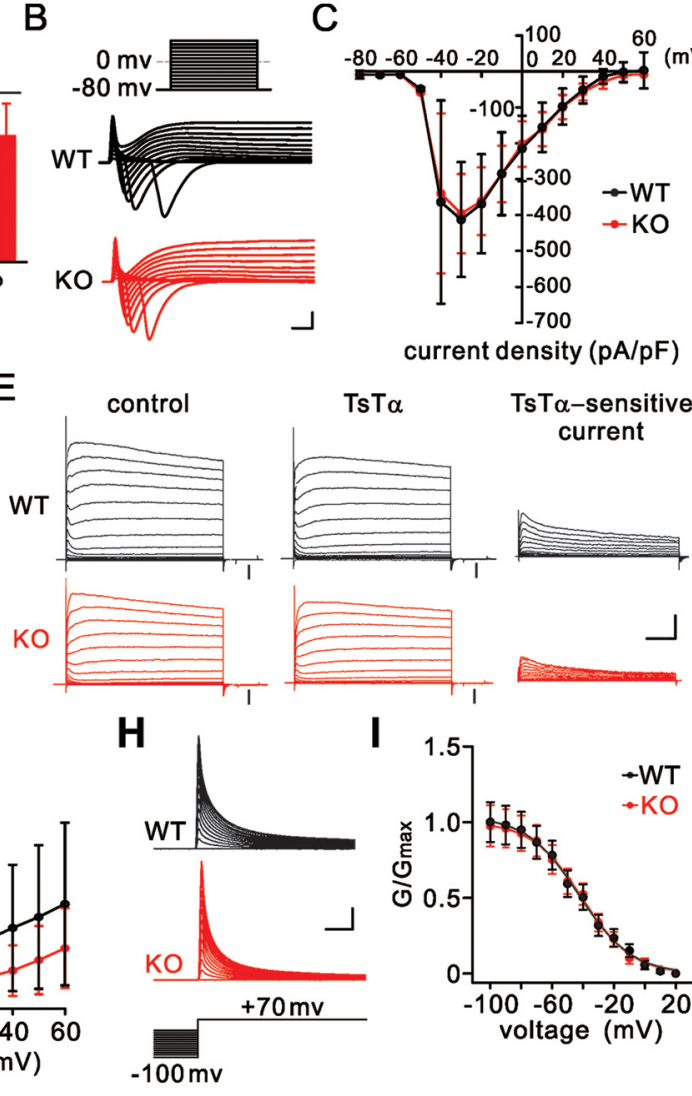

Figure 2. Downregulation of Kv1.2 in $L G / 1^{-1-}$ (KO) mice. A, Temporal cortical lysates (total) and synaptic fractions (P2) from WT and K0 mice probed with antibodies to Nav1 channels and LGI1. Total and P2 fraction of Nav1 were normalized to the corresponding GAPDH, and percentage changes relative to WT are plotted in the histogram. $n=5 / g$ roup. $\boldsymbol{B}$, Whole-cell $\mathrm{Na}_{\text {a }}$ in temporal pyramidal neurons from P14-P17 WT $(n=18)$ and KO $(n=20)$ mice elicited by voltage steps from -80 to $60 \mathrm{mV}$ in $10 \mathrm{mV}$ increments from a holding potential of $-80 \mathrm{mV}$. Calibration: $2 \mathrm{nA}, 1$ ms. $C, I_{\text {Na }}$ peak currents normalized to the corresponding cell capacitances (current density). D, Temporal cortical total and P2 fractions from WT and K0 mice (P16) normalized to corresponding $\mathrm{GAPDH}$, and percentage changes relative to WT are plotted in the histogram. $n=6 /$ group. $\boldsymbol{E}, \mathrm{K}^{+}$currents evoked by voltage-clamp pulses (-80 $\mathrm{mV}$ to $60 \mathrm{mV}$ ) in WT and K0 pyramidal neurons before and after TsT $\alpha$ application (100 nм). Right, Kv1.2 currents (TsT $\alpha$-sensitive currents) obtained by current subtraction. Neurons were perfused with TTX (1 $\mu \mathrm{m}$ )-containing aCSF. Black arrows indicate seal tests. Calibration: $2 \mathrm{nA}$ (total currents), $1 \mathrm{nA}$ (subtracted currents), $100 \mathrm{~ms}$. $\boldsymbol{F}$, Percentage changes in the amplitudes of $\mathrm{K}^{+}$currents evoked at $60 \mathrm{mV}$. WT: $100 \pm 14 \%, n=24$. WT+TsT $\alpha: 77 \pm 24 \%, n=24$. K0: $100 \pm 19 \%, n=23$. K0 +TsT $\alpha: 90 \pm 28 \%, n=23$. G, Plots of current-voltage relationships (I-V curves) of Kv1.2 currents. Inset, Averaged Kv1.2 currents at $40 \mathrm{mV}$ (WT: $950 \pm 816 \mathrm{pA}, n=24 ; \mathrm{KO}: 388 \pm 333$ pA, $n=23$ ). $\boldsymbol{H}$, Inactivation of Kv1.2 currents in WT and K0 neurons tested with 3 sinactivating pre-pulses. Calibration: $1 \mathrm{nA}, 2$ ms. I, Lines represent Boltzmann fits yielding half-activation midpoints of $-42.5 \mathrm{mV}(\mathrm{WT})$ and $-41.7 \mathrm{mV}(\mathrm{KO})$ and slope factors of 16.7 (WT) and 16.0 (K0). WT, $n=15 ; \mathrm{KO}, n=13 .{ }^{*} p<0.05,{ }^{* *} p<0.01$.

and spike width was determined at half the spike amplitude. Interspike interval (ISI) was calculated as the average time between sequential spikes in response to a $300 \mathrm{~ms}$ suprathreshold current (200 pA). The inputoutput relationship between injected currents and spikes was also determined when cells received a series of currents ranging from 30 to $200 \mathrm{pA}$ with a duration of $800 \mathrm{~ms}$. To measure $\mathrm{K}^{+}$currents, TTX $(1 \mu \mathrm{M})$ and $\mathrm{CdCl}_{2}(100 \mu \mathrm{M})$ were added to the aCSF to block $\mathrm{Na}^{+}$and $\mathrm{Ca}^{2+}$ channels and a series of voltage pulses $(500 \mathrm{~ms})$ from $-80 \mathrm{mV}$ to $60 \mathrm{mV}$ were applied under the voltage-clamp configuration. Kv1.2 currents are measured in the steady state (Dodson et al., 2002). The inactivation curves were constructed from peak currents after conversion to conductance, assuming a $\mathrm{K}^{+}$reversal potential of $-85 \mathrm{mV}$ in our recording conditions (Kole et al., 2007), normalized to the maximum conductance, and fitted with a single Boltzmann equation.

Experimental design and statistical analysis. Data were analyzed using Prism 6.0 (GraphPad Software), Excel 2003 (Microsoft), and Igor Pro 6.0 (Wavemetrics). No statistical method was used to determine sample size. SDs for control groups were calculated from the average of all control data. To appropriately choose and justify the statistical tests, we analyzed the normality of the datasets using the Kolmogorov-Smirnov test. If a dataset from unpaired groups was considered normal, a statistical difference was determined using the two-sided Student's $t$ test for two-group 
A

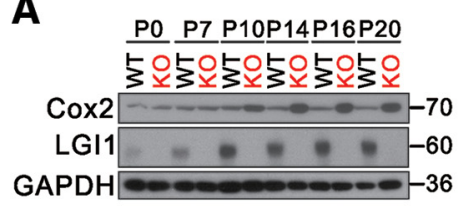

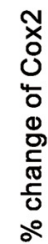

B

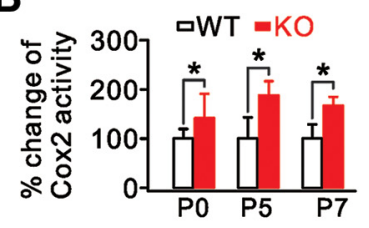

C
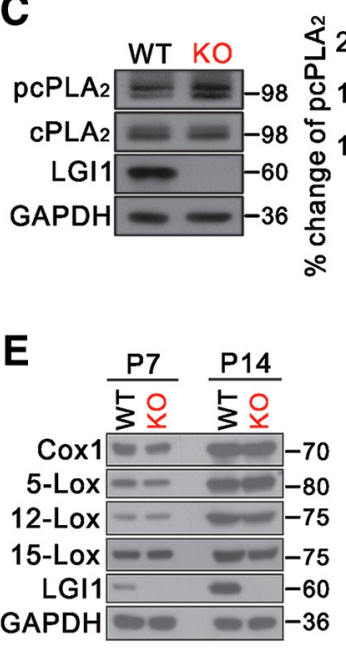

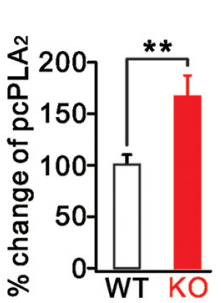

D

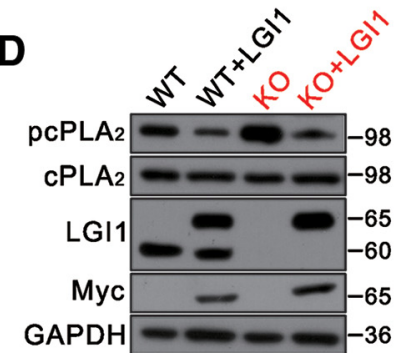

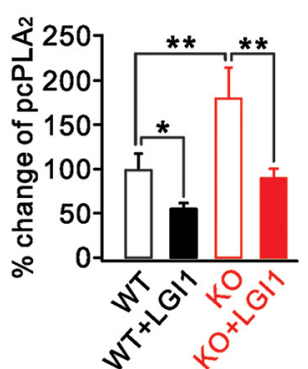
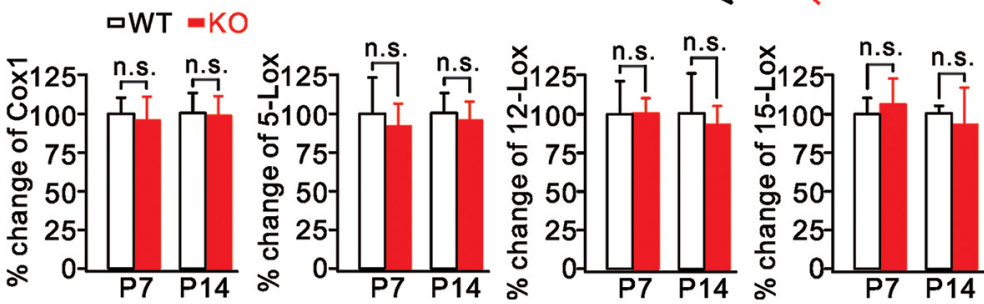

Figure 3. Altered Cox2 and $\mathrm{CPLA}_{2}$ signaling in $L \mathrm{G} / 1^{-1-}$ (KO) mice. $A$, Expression of Cox2 in the developing cortex in WT and K0 mice. $n=5 /$ group. $\boldsymbol{B}$, Percentage changes of Cox2 activity in cortex from WT and K0 mice. $n=5$ /group. C, Temporal cortical lysates from WT and KO mice (P7) immunoblotted with antibodies. GAPDH was the internal control. Histogram represents percentage change of $p c P L A_{2}$ relative to WT. $n=4 /$ group. D. Primary cultured cortical neurons (DIV 14) transfected with myc-tagged myc-LGI1. GAPDH was the internal control. Histogram represents percentage change of pcPLA 2 relative to WT. $n=4$ /group. E, Expression of Cox1, 5-, 12-, 15-lipoxygenase (5-, 12-, 15-Lox), and LGI1 in temporal cortex from WT and K0 mice at P7 and P14. GAPDH was the loading control. Histogram represents percentage changes of each protein relative to the corresponding control. $n=6 /$ group. ${ }^{*} p<0.05,{ }^{* *} p<0.01$.

comparison or the one-way ANOVA test followed by Tukey's post hoc test for multiple comparisons. If not normal, the Mann-Whitney $U$ test was used to determine the differences. For paired groups, a statistical difference was determined using the two-sided paired Student's $t$ test if a dataset was considered normal. Otherwise, the paired Wilcoxon test was used to determine the differences. Survival curves were analyzed by Kaplan-Meier survival estimates using the log-rank test. The covariant correlation test was used to determine distinct effects of drugs on WT and KO mice (Rice, 2006; Huitema, 2011). To do this, linear regression lines concerning the effects of one drug on target currents or proteins derived from untreated and treated groups were first created for both genotypes using the Excel algorithm (Kleinbaum et al., 2007). Next, PASW statistics 18 software (IBM) was used to analyze the covariant correlation between the slopes of the regression lines of WT and $\mathrm{LGI1}^{-/-}$groups. To calculate the significance, the univariate-dependent GLM was selected and genotype was set as the fixed factor (Pallant, 2013). For all analyses, the accepted level of significance was $p<0.05 . n$ indicates the number of animals or cells recorded. Data in the text and figures are presented as mean $\pm \mathrm{SD}$.

\section{Results}

Pyramidal neurons in temporal cortex are hyperexcitable in LGI1 $^{-1-}$ mice

All $L G I 1^{-1-}$ mice displayed typical seizure phenotypes after P10 and died shortly afterward (Fig. 1A) (Chabrol et al., 2010; Fukata et al., 2010; Yu et al., 2010; Silva et al., 2015; Xie et al., 2015; Yokoi et al., 2015). In ADLTE patients, auditory auras arising in the lateral temporal lobe are followed by generalized seizures (Ottman et al., 1995). Therefore, we performed whole-cell recordings in layer $2 / 3$ pyramidal neurons of the temporal cortex from $L G I 1^{-1-}$ and WT littermates aged P14-P17, when $L G I 1^{-/-}$mice suffer from epilepsy but before their death. At this stage, LGI1 ${ }^{-1-}$ neurons had a more hyperpolarized voltage threshold for an ac- tion potential than WT neurons (Fig. $1 B, C$ ), as indicated by the rate of change $(\mathrm{d} V / \mathrm{d} t)$ of membrane potential versus membrane potential (Fig. 1D). Consistently, the minimal current eliciting an action potential (rheobase) in $L G I 1^{-/-}$neurons was significantly smaller than in WT neurons (Table 1). Neither the amplitude nor half-width of the action potential was different in $L G I 1^{-1-}$ neurons (Table 1). These results indicate that LGI1 influences the generation of action potentials in pyramidal neurons. Neither the resting membrane potential nor the input resistance differed between WT and $L G I 1^{-1-}$ neurons (Table 1). We next examined the intrinsic excitability of pyramidal neurons by injecting depolarizing currents. The ISI, which is extensively used to assess intrinsic neuronal excitability (Wen et al., 2010; Yu et al., 2010), was significantly decreased by LGI1 ablation (Fig. $1 E$ ). This result was corroborated by input-output curves (injected current vs number of spikes), which were generated for WT and LGI1 ${ }^{-1-}$ neurons based on previous work (Gasselin et al., 2015) (Fig. 1F). In conclusion, LGI1 ablation alters the intrinsic properties of layer 2/3 pyramidal neurons.

To determine whether LGI1 deletion only affects these neurons, we examined layer 5 pyramidal neurons and interneurons in the temporal cortex. We found that the excitability of layer 5 neurons was increased in $L G I 1^{-1-}$ mice, as shown by a reduced ISI (Fig. $1 G$ ) and rheobase (Table 2). In agreement with previous work (Boillot et al., 2014), we found that interneurons were not affected by LGI1 deficiency because neither the excitability (Fig. $1 H$ ) nor the rheobase was changed in these neurons (Table 2). In addition, $L G I 1^{-/-}$pyramidal neurons were still hyperexcitable when picrotoxin was added to block GABAergic transmission (Fig. 1I; Table 2) or mecamylamine (MEC) and atropine were added to block cholinergic transmission (Fig. 1J; Table 2). These 

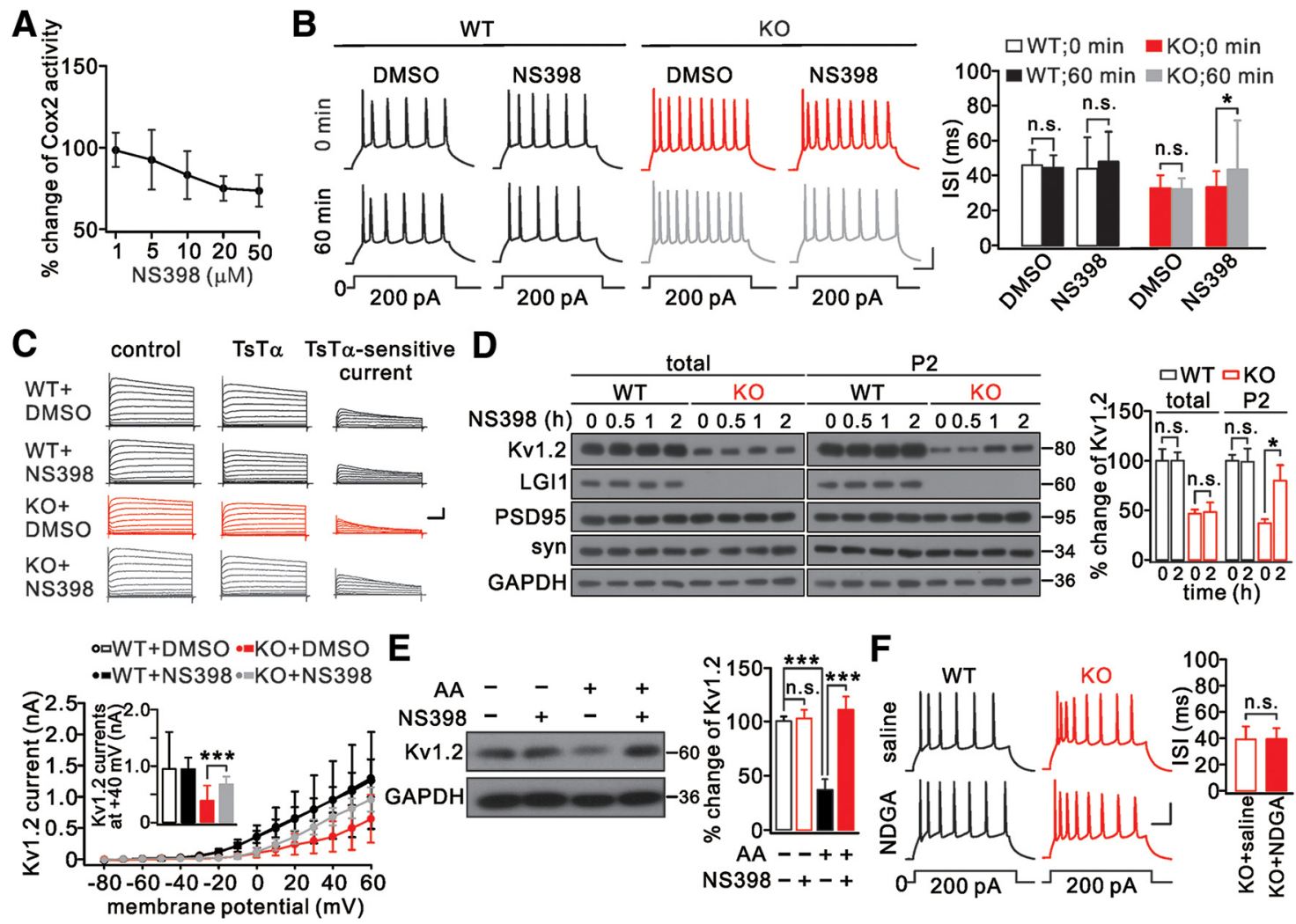

Figure 4. Cox2 inhibition restored Kv1.2. A, Dose-response curve for the effect of NS398 on Cox2 activity in $\mathrm{GG}^{-1-}$ (KO) cortical slices. Data are presented as percentage change relative to the untreated group. $n=5 /$ group. B, Spikes were induced every $5 \mathrm{~min}$ in WT and KO layer 2/3 neuron perfused with aCSF containing DMSO or NS398 (20 $\mu \mathrm{M})$. Calibration: $20 \mathrm{mV}$, $50 \mathrm{~ms}$. Right, ISIs. C, $\mathrm{K}^{+}$currents evoked by voltage-clamp pulses $(-80$ to $60 \mathrm{mV})$ in WT and K0 neurons before and after addition of TsT $\alpha(100 \mathrm{~nm})$. Right, Kv1.2 currents were obtained by current subtraction. Calibration: $2 \mathrm{nA}$ (total currents) or $1 \mathrm{nA}$ (subtracted currents), $100 \mathrm{~ms}$. Bottom, $I-V$ curves of Kv1.2 currents. Inset, Averaged Kv1.2 currents at $40 \mathrm{mV}$ (WT+DMS0: $950 \pm 639 \mathrm{pA}, n=16$; WT+NS398: $949 \pm 208 \mathrm{pA}, n=19 ; \mathrm{KO}+\mathrm{DMS0}: 381 \pm 252 \mathrm{pA}, n=16 ; \mathrm{K} 0+\mathrm{NS} 398: 682 \pm 140 \mathrm{pA}, n=17$ ). D, Levels of Kv1.2, PSD95, synaptophysin (syn), and LG11 in cortical slices with NS398 $(20 \mu \mathrm{M})$ at different time points. For each time point, 5 slices from WT or K0 mice were used. GAPDH was the loading control. Right, Percentage changes of Kv1.2 relative to WT during NS398 treatment. E, AA $(20 \mu \mathrm{M})$ decreased, but NS398 $(20 \mu \mathrm{M})$ reversed, Kv1.2 expression in cultured cortical neurons (DIV 14). GAPDH was the internal control. Histogram represents the percentage

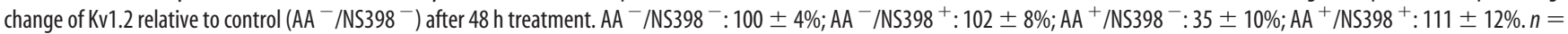
$5 /$ group. $\boldsymbol{F}$, Spikes and ISIs of layer 2/3 pyramidal neurons from WT and $K 0$ mice in response to prolonged current injection and exposed to NDGA $(50 \mu \mathrm{M}) .{ }^{*} p<0.05$, ${ }^{* * *} p<0.001$.

data indicate that neither GABAergic nor cholinergic interneurons contribute to the hyperexcitability of pyramidal neurons. Furthermore, layer $2 / 3$ pyramidal neurons in the prefrontal cortex from $L G I 1^{-1-}$ mice (P14-P17) also exhibited higher excitability, as shown by a reduced ISI (Fig. $1 K$ ) and rheobase (Table 2 ). In addition, we noted that the resting membrane potential of temporal L2/3 pyramidal neurons was more positive than that of prefrontal neurons (Tables 1,2), suggesting that temporal neurons are more excitable than prefrontal neurons.

\section{Kv1.2 is downregulated in $\mathrm{LGI1}^{-/-}$mice}

We next investigated how the intrinsic excitability is elevated in $L G I 1^{-1-}$ mice. We focused on voltage-gated channels because they are critical to the initiation of the action potential and excitability. Several lines of evidence suggested that the voltage-gated $\mathrm{Na}^{+}$channels in pyramidal neurons were unrelated to the hyperexcitability caused by LGI1 ablation: (1) the levels of the major subunits of $\mathrm{Na}^{+}$channels, Nav1.1, Nav1.2, and Nav1.6, were unaltered at the synapses of $L G I 1^{-1-}$ mice (P16) (Fig. 2A); (2) the amplitude of the action potential, which is determined by $\mathrm{Na}^{+}$ channels (Hille, 2001), was unchanged (Table 1); and (3) the total $\mathrm{Na}^{+}$currents were not different in LGI1 ${ }^{-/-}$mice (P14-P17) (Fig. $2 B, C)$.

We then investigated whether LGI1 deficiency affects Kv1 channels because they regulate the action potential threshold and intrinsic excitability (Hille, 2001; Guan et al., 2006). To this end, we isolated LGI1 and Kv1.2 channels in total and synaptic fractions from temporal cortex (Fukata et al., 2010). Our data showed that Kv1.2 in both fractions was significantly reduced in $L G I 1^{-1-}$ mice (P16), whereas Kv1.4 and Kv1.6 were unaltered (Fig. 2D). Next, we applied a series of voltage-clamp pulses to pyramidal neurons from WT and LGI1 ${ }^{-1-}$ mice (P14-P17) perfused with TTX-containing aCSF. Based on previous work (Dodson et al., 2002; Li et al., 2011), the steady-state currents were subtracted from the overall $\mathrm{K}^{+}$currents when a specific Kv1.2 antagonist, TsT $\alpha$, was added to the aCSF to evoke Kv1.2 currents (Fig. 2E). In WT neurons, the overall $\mathrm{K}^{+}$currents were significantly reduced when TsT $\alpha$ was added, but the reduction was not significant in $L G I 1^{-1-}$ neurons (Fig. $2 F$ ). Moreover, the amplitudes of TsT $\alpha$ sensitive components (Kv1.2 currents) were significantly decreased in $L G I 1^{-1-}$ neurons (Fig. $2 G$ ). These results indicate that LGI1 ablation inhibits Kv1.2 currents. To further elucidate the roles of LGI1, we assessed the inactivation of Kv1.2 in layer 2/3 neurons by depolarizing prepulses (Kole et al., 2007). We found that the inactivation of Kv1.2 was not affected by LGI1 ablation (Fig. $2 H$ ), as indicated by kinetics analysis (Fig. 2I).

\section{LGI1 drives $\mathrm{CPLA}_{2}$-Cox2 signaling}

The inflammatory factor Cox 2 is increased in the brains of patients and animals experiencing seizures (Marcheselli and Bazan, 
Table 3. Electrophysiological properties of L2/3 pyramidal neurons treated with NS398

\begin{tabular}{|c|c|c|c|c|c|c|c|c|}
\hline \multirow[b]{3}{*}{ Parameter } & \multicolumn{4}{|l|}{ WT (P14-P17) } & \multicolumn{4}{|l|}{ K0 (P14-P17) } \\
\hline & \multicolumn{2}{|l|}{ DMSO } & \multicolumn{2}{|l|}{ NS398 } & \multicolumn{2}{|l|}{ DMSO } & \multicolumn{2}{|l|}{ NS398 } \\
\hline & $0 \min$ & $60 \mathrm{~min}$ & $0 \mathrm{~min}$ & $60 \mathrm{~min}$ & $0 \mathrm{~min}$ & $60 \min$ & $0 \mathrm{~min}$ & $60 \min$ \\
\hline Rheobase (pA) & $85 \pm 20$ & $85 \pm 40$ & $86 \pm 25$ & $85 \pm 29$ & $71 \pm 24.7$ & $72 \pm 37$ & $-73.8 \pm 17$ & $80 \pm 22^{* *}$ \\
\hline RMP (mV) & $-65 \pm 10$ & $-66 \pm 5$ & $-65 \pm 15$ & $-67 \pm 15$ & $-64 \pm 12$ & $-63 \pm 12$ & $-64 \pm 6$ & $-69 \pm 11^{*}$ \\
\hline Input resistance ( $\mathrm{m} \Omega$ ) & $166 \pm 15$ & $171 \pm 20$ & $172 \pm 15$ & $171 \pm 15$ & $172 \pm 25$ & $171 \pm 25$ & $170 \pm 33$ & $172 \pm 39$ \\
\hline
\end{tabular}

${ }^{*} p<0.05,{ }^{* *} p<0.01$, compared with $\mathrm{KO}+\mathrm{NS} 398+0 \mathrm{~min} . \mathrm{KO}: \mathrm{LGI}^{-1-}$.

Table 4. Covariant correlation tests of drug effects between genotypes

\begin{tabular}{|c|c|c|c|c|}
\hline \multirow[b]{2}{*}{ Drugs/proteins } & \multirow[b]{2}{*}{ On target (figure) } & \multicolumn{2}{|l|}{ Regression lines } & \multirow[b]{2}{*}{ Significance $(p)$} \\
\hline & & WT & KO & \\
\hline LGI1 & pcPLA (Fig. 3D) & $y=-89.8 x+269$ & $y=-43.5 x+142$ & $0.046^{*}$ \\
\hline NS398 & $\mathrm{K}^{+}$current at $+40 \mathrm{mV}$ (Fig. 40 ) & $y=-109.1 x+1166.8$ & $y=-228.9 x+223.8$ & $0.049^{*}$ \\
\hline NS398 & Synaptic Kv1.2 (Fig. 4D) & $y=-x+101$ & $y=43 x-6.2$ & $0.0001^{* * *}$ \\
\hline NDGA & ISI (Fig. 4F) & $y=0.3 x+49.4$ & $y=0.3 x+38.7$ & 0.999 \\
\hline Celecoxib & ISI (Fig. 5C) & $y=1.6 x+42.9$ & $y=9.9 x+27.2$ & $0.032^{*}$ \\
\hline Celecoxib & $\mathrm{K}^{+}$current at $+40 \mathrm{mV}$ (Fig. $5 E$ ) & $y=-123.4 x+1181.1$ & $y=359 x+93.7$ & $0.01^{* *}$ \\
\hline Celecoxib & Synaptic Kv1.2 (Fig. 5F) & $y=-0.8 x+100.3$ & $y=64 x-50.2$ & $0.0001^{* * *}$ \\
\hline Celecoxib & Synaptic Cox2 (Fig. 5F) & $y=3.5 x+97.3$ & $y=-1158.5 x-899$ & $0.0001^{* * *}$ \\
\hline
\end{tabular}

1996; Das et al., 2012; Rojas et al., 2014). Thus, we speculated that Cox2 dysregulation occurs in $\mathrm{LGI1}^{-/-}$mice when they develop epilepsy. So we measured the expression of LGI1 and Cox2 in temporal cortex before and after the occurrence of seizures. In agreement with previous work (Zhou et al., 2009), LGI1 expression was rather limited at birth but steadily increased afterward (Fig. 3A). Interestingly, we found that Cox2 activity was significantly enhanced in $\mathrm{LGI1}^{-1-}$ mice after birth but before seizures occurred (Fig. $3 B$ ) when its expression showed no further increase (Fig. $3 A$ ), implying that LGI1 deficiency promotes Cox2 activity.

Activated $\mathrm{CPLA}_{2}$ produces arachidonic acid (AA), a substrate for Cox2, and is involved in various pathological conditions (Farooqui et al., 1997). Because cPLA 2 and Cox2 are functionally coupled (Naraba et al., 1998; Scott et al., 1999; Takano et al., 2000), we investigated whether LGI1 deletion also interrupts $\mathrm{CPLA}_{2}$ signaling. Indeed, we found that phosphorylated $\mathrm{CPLA}_{2}$ $\left(\mathrm{pcPLA}_{2}\right)$ was enhanced in $\mathrm{LGI1}^{-1-}$ temporal cortex (P7), whereas its total expression was unchanged (Fig. 3C). Furthermore, cortical neurons from WT and $L G I 1^{-1-}$ mice cultured for $14 \mathrm{~d}$ (DIV 14) were transfected with either naive control or mycLGI1. Consistent with the in vivo study, we found higher $\mathrm{pcPLA}_{2}$ in $L G I 1^{-1-}$ neurons than in WT neurons (Fig. 3D). Importantly, replenishing LGI1 by transfecting myc-LGIl into both the WT and $L G I 1^{-1-}$ groups was sufficient to attenuate the level of pc$\mathrm{PLA}_{2}$ (Fig. 3D), whereas covariance analyses showed that the effect of LGI1 was more prominent in $L G I 1^{-1-}$ than in WT tissues (Table 4). These data demonstrate that LGI1 drives $\mathrm{CPLA}_{2}$-AACox2 signaling. AA is also a substrate of other enzymes, such as Cox1 and lipoxygenase (O'Banion, 1999). We therefore determined whether LGI1 deletion leads to abnormal Cox1 and lipoxygenase signaling. Against this assumption, the levels of Cox1 and all three isoforms of lipoxygenase (5-, 12-, and 15-lipoxygenase) were the same in $L G I 1^{-1-}$ and WT mice (Fig. 3E).

Cox2 inhibition recovers Kv1.2 channels in $\mathrm{LGI1}^{-/-}$mice The coincident changes of Cox 2 and Kv1.2 by LGI1 deletion encouraged us to investigate whether Cox 2 suppression can re-
Table 5. Electrophysiological properties of L2/3 neurons treated with NDGA

\begin{tabular}{lccccc}
\hline & WT (P14-P17) & & & K0 (P14-P17) \\
\cline { 2 - 3 } \cline { 6 - 6 } Parameter & Saline & NDGA & & Saline & NDGA \\
\hline ISI (ms) & $49.7 \pm 11.2$ & $50.1 \pm 11.5$ & & $39.1 \pm 7.9$ & $39.4 \pm 9.2$ \\
Rheobase (pA) & $130 \pm 32$ & $129 \pm 28$ & & $100 \pm 34$ & $91 \pm 41$ \\
RMP (mV) & $-67 \pm 4$ & $-64 \pm 5$ & & $-64 \pm 6$ & $-63 \pm 5$ \\
Input resistance (M $\Omega)$ & $141 \pm 28$ & $146 \pm 32$ & & $147 \pm 28$ & $152 \pm 36$ \\
No. of cells (mice) & $17(5)$ & $22(5)$ & $33(7)$ & $27(5)$ \\
\hline
\end{tabular}

$\mathrm{KO}: \mathrm{LGI1}{ }^{-/-}$.

store Kv1.2 currents and neuronal excitability. Our experiments showed that Cox 2 activity was suppressed by its selective inhibitor, NS398, with a saturation concentration of $20 \mu \mathrm{M}$ (Fig. 4A). Then, spikes were induced in layer $2 / 3$ pyramidal neurons when slices were perfused with aCSF containing DMSO or NS398 (20 $\mu \mathrm{M})$. We found that the ISI was significantly increased in the $L G I 1^{-1-}$ group after 60 min NS398 exposure (Fig. 4B; Table 3). Meanwhile, the rheobase of $L G I 1^{-1-}$ neurons was almost restored to normal by NS398 (Table 3). Next, voltage-clamp pulses were applied to these neurons when TsT $\alpha$ plus DMSO or NS398 were added to the bath. Kv1.2 currents were unchanged by treatment with either DMSO or NS398 in WT neurons, but they were significantly restored in $\mathrm{LGI1}^{-/-}$neurons perfused with NS398 (Fig. 4C). Moreover, covariance correlation tests showed that the effect of NS398 was stronger in KO neurons than in WT neurons (Table 4). Meanwhile, the resting membrane potential was more hyperpolarized after NS398 treatment (Table 3).

To confirm the electrophysiological recordings, cortical slices were treated with NS398 and the expression of Kv1.2 was measured at different time points. In slices from WT mice (P16), NS398 did not affect Kv1.2 expression (Fig. 4D). In slices from $L G I 1^{-1-}$ mice (P16), synaptic Kv1.2 progressively increased while the total did not change (Fig. $4 D$ ). Correlation tests showed that LGI1-knock-out affected the synaptic expression of Kv1.2 more markedly in KO neurons than in WT neurons (Table 4). To determine the synergistic effects of Cox 2 and $\mathrm{CPLA}_{2}$ on $\mathrm{Kv1} 1.2$, we treated cultured WT cortical neurons (DIV 14) with AA and 
A

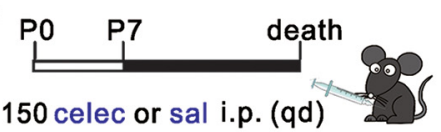

B

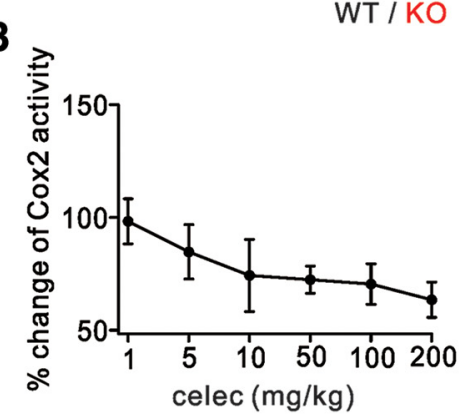

E

$\circ \mathrm{WT}+\mathrm{sal} \quad \bullet \mathrm{KO}+\mathrm{sal}$

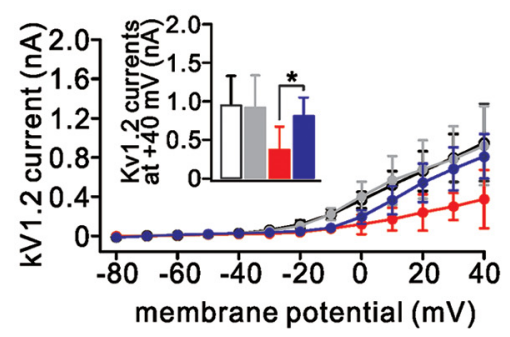

C

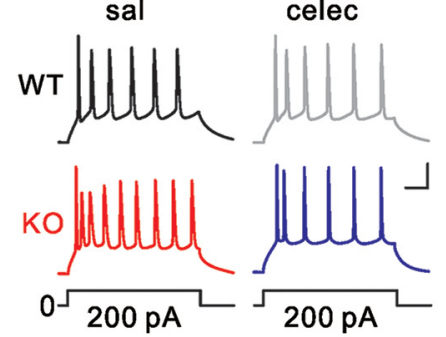

D

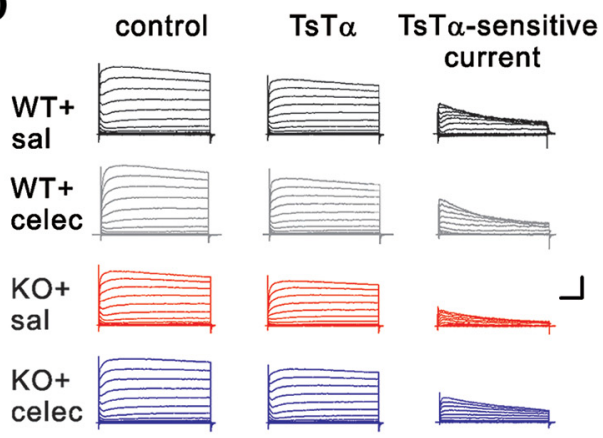

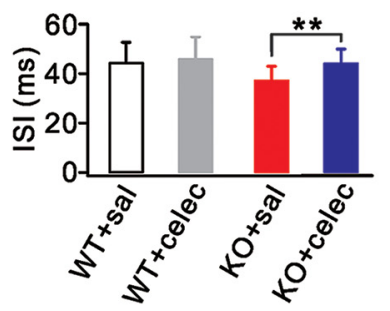

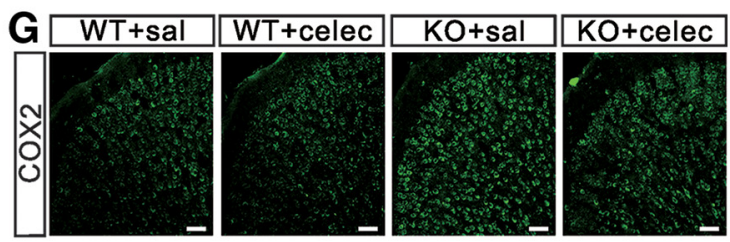

F
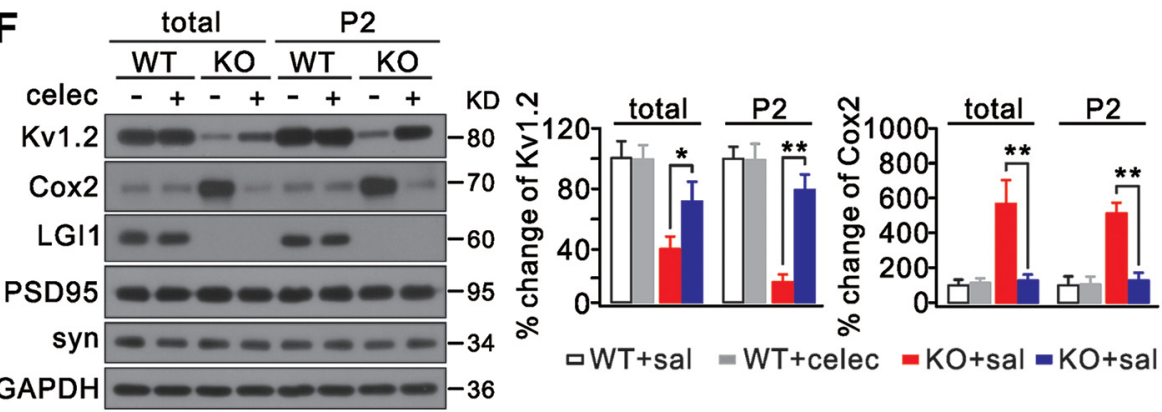

Figure 5. Rescue effects of celecoxib on Cox2 and Kv1.2. A, WT and $L G / 1^{-1-}$ (KO) mice (P7) were randomly selected and received an intraperitoneal injection of $10 \mathrm{mg} / \mathrm{kg}$ celecoxib (celec) or saline (sal) daily until death. $\boldsymbol{B}$, Dose-response curve for the effect of celecoxib on Cox2 activity in K0 mice. Data are presented as percentage change relative to the untreated group. $n=5 /$ group. C, Sample spikes in response to prolonged current injection in layer $2 / 3$ neurons. Bottom, Averaged ISIs. $\boldsymbol{D}, \mathrm{K}^{+}$currents evoked by voltage-clamp pulses ( -80 to $60 \mathrm{mV}$ ) in pyramidal neurons from WT and K0 mice treated with saline or celecoxib. Left, Traces recorded before TsT $\alpha$ (100 nm) application. Middle, Traces recorded after TsT $\alpha$ (100 nm) application. Right, Kv1.2 currents were obtained by subtraction. $E, I-V$ curves of TsT $\alpha$-sensitive currents. Inset, Averaged Kv1.2 currents at $40 \mathrm{mV}$. WT + saline: $921 \pm 385 \mathrm{pA}, n=23$. WT + celecoxib: $901 \pm 422 \mathrm{pA}, n=23$. K0 + saline: $390 \pm$ $305 \mathrm{pA}, n=23 . \mathrm{KO}+$ celecoxib: $812 \pm 244 \mathrm{pA}, n=23 . \boldsymbol{F}$, Cortical total and P2 fractions from WT + saline, WT + celecoxib, KO + saline, and K0 + celecoxib groups probed with antibodies to Kv1.2, Cox2, LGI1, PSD95, and synaptophysin (syn). GAPDH was the internal control. Right, Percentage changes of expressions of Kv1.2 and Cox2 relative to WT. $n=6 /$ group. G, Cox2 distribution in coronal cortical sections from WT + saline, WT+ celecoxib, K0+ saline, and K0+celecoxib groups. $n=5 /$ group. Scale bars, $50 \mu \mathrm{m}$. ${ }^{*} p<0.05,{ }^{* *} p<0.01$.

NS398 individually or together for $48 \mathrm{~h}$, and found that AA markedly reduced Kv1.2 expression whereas this was robustly reversed by NS398 (Fig. 4E). These results suggest that Cox2 and cPLA 2 work together to control synaptic Kv1.2.

We also investigated whether an inhibitor of lipoxygenase changes neuronal excitability. Spikes were induced in layer $2 / 3$ pyramidal neurons from WT and $L G I 1^{-1-}$ mice when slices were perfused with nordihydroguaiaretic acid (NDGA; $50 \mu \mathrm{M}$ ), an inhibitor of lipoxygenase, for $60 \mathrm{~min}$. Likewise, NDGA was unable to change the ISI and rheobase in either preparation (Fig. 4F; Table 5). This result was also corroborated by correlation test showing that the NDGA effect did not differ between WT and LGI1 ${ }^{-1-}$ neurons (Table 4). Combined with the results shown in Figure 3E, these data indicate that lipoxygenase does not contribute to the abnormal neuronal excitability induced by LGI1 deletion.

\section{Celecoxib decreases Cox2 expression and rescues the Kv1.2} defect in $\mathrm{LGI1}{ }^{-1-}$ mice

Because NS398 reverses Kv1.2 expression and neuronal hyperexcitability, we investigated whether these effects in $L G I 1^{-1-}$ mice can be reproduced pharmacologically in vivo. Celecoxib, a selective Cox2 inhibitor, has been approved by the FDA to treat osteoarthritis (Zeng et al., 2015), rheumatoid arthritis (Lipsky and
Table 6. Electrophysiological properties of $L 2 / 3$ neurons treated with celecoxib

\begin{tabular}{lccccc}
\hline & WT (P16) & & & K0 (P16) & \\
\cline { 2 - 3 } \cline { 6 - 6 } Parameter & Saline & Celecoxib & & Saline & Celecoxib \\
\hline ISI (ms) & $44.5 \pm 8.5$ & $46.1 \pm 9.2$ & & $37.7 \pm 6.5$ & $44.3 \pm 6.1^{* *}$ \\
Rheobase (pA) & $117 \pm 22$ & $115 \pm 23$ & & $94 \pm 15$ & $116 \pm 23^{* *}$ \\
RMP (mV) & $-66 \pm 4$ & $-66 \pm 5$ & & $-65 \pm 5$ & $-67 \pm 5$ \\
Input resistance (MS) & $153 \pm 18$ & $155 \pm 18$ & $156 \pm 20$ & $154 \pm 19$ \\
No. of cells (mice) & $21(5)$ & $22(5)$ & $26(5)$ & $23(5)$ \\
\hline
\end{tabular}

${ }_{* * \mathrm{p}}<0.01$ compared with $\mathrm{KO}+$ saline. KO: $\mathrm{LGI}^{-1}$

Isakson, 1997), and menstrual symptoms (Edelman et al., 2013). So, celecoxib was injected intraperitoneally into $L G I 1^{-1-}$ mice daily from P7 until death (Fig. 5A). The dose-response curve of celecoxib (1-200 mg/kg) showed a near saturation effect at 10 $\mathrm{mg} / \mathrm{kg}$ in $\mathrm{LGI1}^{-1-}$ mice (P16) (Fig. 5B). At $10 \mathrm{mg} / \mathrm{kg}$, celecoxib significantly increased the ISI in $L G I 1^{-1-}$ neurons but had no effect on WT neurons (Fig. 5C). The covariant correlation tests showed that celecoxib effects were irrelevant between WT and $L G I 1^{-/-}$neurons (Table 4). The rheobase for the action potential in $L G I 1^{-1-}$ neurons also significantly increased (Table 6). These data indicate that celecoxib decreases neuronal excitability in $L G I 1^{-1-}$ mice. We further found that celecoxib effectively restored 
A

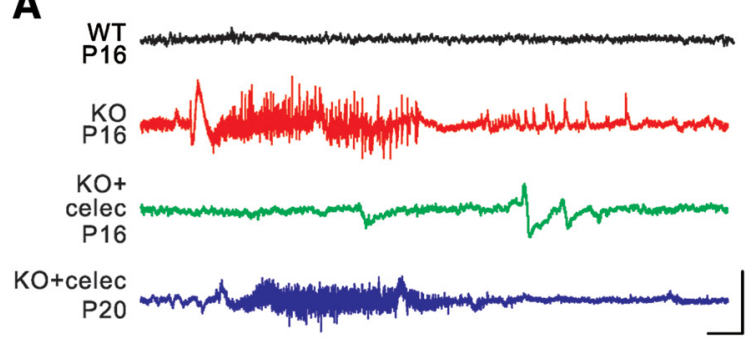

D

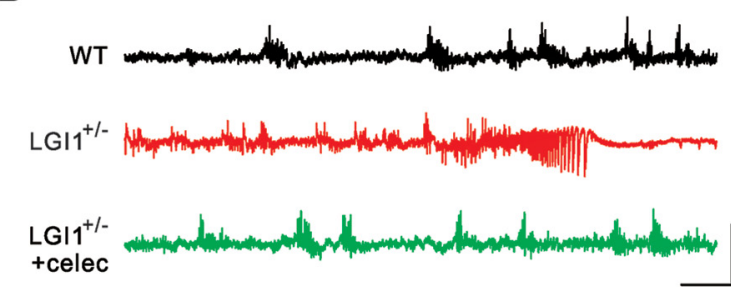

B

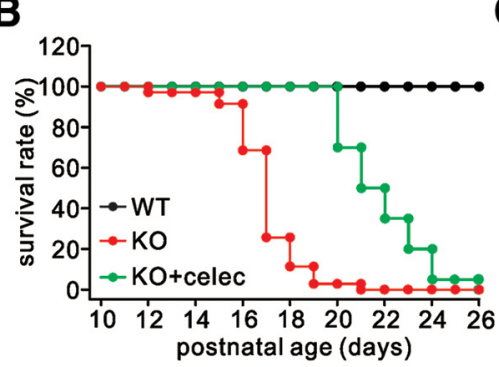

C

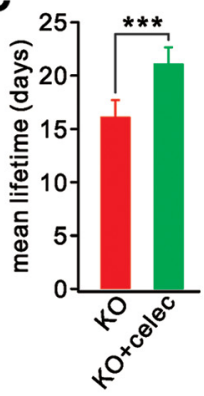

E

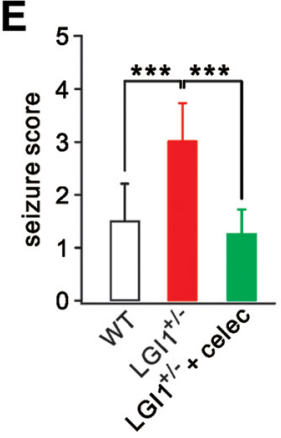

F

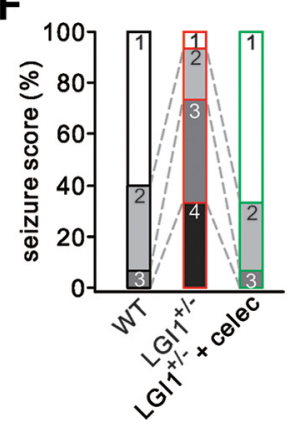

Figure 6. Reduced seizure susceptibility and extended lifetime in $\mathrm{LGI}^{-1-}(\mathrm{KO})$ mice after celecoxib injection. $A$, Cortical EEG recordings from WT and KO mice. The epileptiform discharge was remarkably inhibited in celecoxib-treated K0 mice at P16 but recurred after P20. B, Kaplan-Meier survival curves of WT ( $n=35), \mathrm{KO}(n=35)$, and K0 + celecoxib ( $n=20)$ groups. $\boldsymbol{C}$, Histogram of average lifetimes of KO $(16.0 \pm 1.7 \mathrm{~d}, n=35)$ and KO + celecoxib $(21.1 \pm 2.2 \mathrm{~d}, n=20)$ mice. $\boldsymbol{D}$, EEG recordings from WT, $L G / 1^{+/-}$, and celecoxib-treated $L G / 1^{+/-}$mice (P35) when PTZ was injected intraperitoneally. $\boldsymbol{E}$, Averaged seizure scores in mice. WT, $1.5 \pm 0.7(n=15) ; L G / 1^{+/-}, 3.0 \pm 0.7(n=15) ; L G / 1^{+/-}+$celecoxib, $1.3 \pm 0.4(n=15)$. $\boldsymbol{F}$, Quantification of reactions to PTZ injection. ${ }^{* * *} p<0.001$.

Kv1.2 currents in $L G I 1^{-/-}$pyramidal neurons (Fig. $5 D, E$ ), suggesting that celecoxib rescues Kv1.2 channels. Correlation tests indicated that LGI1-knock-out affected Kv1.2 currents more strongly in $L G I 1^{-1-}$ than in WT neurons (Table 4). These recordings were corroborated by Kv1.2 and Cox2 expression in $\mathrm{LGI1}^{-1-}$ mice (P16) treated with celecoxib, showing that Cox2 was reduced and Kv1.2 was increased (Fig. 5F). Cox2 staining was also significantly reduced in $L G I 1^{-l-}$ mice treated with celecoxib (Fig. 5G). Moreover, the level of Cox 2 mRNA was increased in $L G I 1^{-1-}$ mice (P16) but was reduced after they were treated with celecoxib, showing that the normalized changes of Cox 2 mRNA were $2.6 \pm 1.2$-fold $(n=5)$ in the $L G I 1^{-1-}+$ saline group and $1.4 \pm$ 0.6 -fold $(n=5)$ in the $L G I 1^{-1-}+$ celecoxib group $(p<0.01)$. Covariant correlation tests indicated that LGI1 deficiency had more prominent effects on the synaptic expression of Kv1.2 and Cox2 in $\mathrm{LGI1}^{-1-}$ than in WT tissues (Table 4). These results demonstrate that celecoxib decreases Cox2 expression and restores Kv1.2 in $\mathrm{LGI1}^{-1-}$ mice.

Celecoxib alleviates seizure susceptibility and extends the life of $L G I 1^{-/-}$mice

Given that celecoxib rescues neuronal hyperexcitability, a core question is whether the seizure phenotype can be ameliorated and the lifespan prolonged in $L G I 1^{-1-}$ mice. We recorded EEG in the cerebral cortex and evaluated the behavioral seizures in mice (P14-P22) (Chabrol et al., 2010; Fukata et al., 2010). The traces from WT mice were relatively smooth without detectable epileptic activity (Fig. 6A). In contrast, recurrent spontaneous seizures were detected in all $L G I 1^{-1-}$ mice when recorded at P14 or P15 (Table 7). Typically, the epileptic activity was relatively fast $(70-100 \mathrm{~Hz}$ ) but with a low voltage (Fig. $6 \mathrm{~A}$ ), corresponding to the increased frequency and unchanged amplitude of spikes in pyramidal neurons. The seizures lasted for $59.1 \pm 22.4 \mathrm{~s}(n=42)$ and finally ended following flattened EEG activity (Fig. 6A). Cele-
Table 7. Characteristics of spontaneous seizures

\begin{tabular}{|c|c|c|c|c|c|c|}
\hline $\begin{array}{l}\text { Mouse } \\
\text { condition }\end{array}$ & $\begin{array}{l}\text { No. of mice } \\
\text { with seizures } \\
\text { (total } n)\end{array}$ & $\begin{array}{l}\text { No. of } \\
\text { seizures }\end{array}$ & $\begin{array}{l}\text { Age range } \\
\text { of recordings } \\
\text { (days) }\end{array}$ & $\begin{array}{l}\text { Age range } \\
\text { at seizure } \\
\text { onset (days) }\end{array}$ & $\begin{array}{l}\text { Frequency } \\
\text { range of } \\
\text { seizures }(/ \mathrm{h})\end{array}$ & $\begin{array}{l}\text { Mean } \\
\text { seizure } \\
\text { duration (s) }\end{array}$ \\
\hline$L G / 1^{-I-}$ & $5(5)$ & 42 & $14-18$ & $14-15$ & $0.25-$ & $59.1 \pm 22.4$ \\
\hline $\begin{array}{r}L G / 1^{-1-}+ \\
\text { celecoxib }\end{array}$ & $4(4)$ & 25 & $14-23$ & $19-20$ & $0.25-0.75$ & $43.5 \pm 9.3$ \\
\hline
\end{tabular}

coxib inhibition significantly delayed the occurrence of epileptic seizures in $L G I 1^{-1-}$ mice (Fig. $6 A$ ). The seizures, unfortunately, recurred in the celecoxib-treated $L G I 1^{-1-}$ mice at later stages (P20) (Table 7). All $L G I 1^{-1-}$ mice died prematurely after an average of $16.0 \pm 1.7 \mathrm{~d}(n=35)$ (Fig. $6 B, C)$. In contrast, all celecoxib-treated $L G I 1^{-/-}$mice survived beyond this period $(21.1 \pm 2.2 \mathrm{~d} ; n=20$; Fig. $6 C$; Table 7$)$. Because $L G I 1^{+/-}$mice also display increased seizure susceptibility to PTZ (Fukata et al., 2010), we continued to examine PTZ-induced seizure susceptibility in $L G I 1^{+/-}$mice (P35) with or without celecoxib treatment. PTZ injection ( $45 \mathrm{mg} / \mathrm{kg}$ i.p.) induced either no response or myoclonic jerks in different groups to different degrees within $30 \mathrm{~min}$, corresponding to scores 1-4 (Ferraro et al., 1999). Consistent with previous work (Fukata et al., 2010), seizure severity was significantly higher in $L G I 1^{+/-}$mice, as shown by more frequent generalized seizures (Fig. 6D) and higher seizure scores (Fig. $6 E)$. Most $L G I 1^{+/-}$mice displayed Stage 3 or 4 , whereas most WT mice were at Stage 1 or 2 (Fig. $6 F$ ). Celecoxib inhibition greatly decreased the susceptibility to PTZ, as shown by less frequent generalized seizures (Fig. 6D) and lower seizure scores and stages (Fig. 6E,F). In summary, celecoxib alleviates seizure susceptibility and extends the lifespan of $L G I 1^{-1-}$ mice.

\section{Discussion}

Here, we elucidated the hyperexcitability of temporal cortical pyramidal neurons in $L G I 1^{-1-}$ mice. Loss of LGI1 decreased the 
expression of Kv1.2, enhanced the intrinsic excitability, and caused epilepsy, which might be mediated by altered cPLA ${ }_{2}-\mathrm{Cox} 2$ signaling. Importantly, we showed that celecoxib was sufficient to recover the defective Kv1.2 in pyramidal neurons and thereby decrease neuronal excitability. Accordingly, we suggest that celecoxib treatment is a promising approach to managing ADLTE.

We found that the intrinsic excitability was increased in temporal and prefrontal cortical neurons in $L G I 1^{-/-}$mice, consistent with recent work showing that LGI1 modulates intrinsic excitability through Kv1 channels (Seagar et al., 2017). Therefore, we propose that seizures in $L G I 1^{-1-}$ mice are due, at least partly, to epileptiform activity in cortical neurons. Indeed, it has been shown that nonsynaptic mechanisms play critical roles in modulating the epileptogenicity in patients suffering from temporal lobe epilepsy (Haglund and Hochman, 2005). 4-Phenylbutyrate (4PBA), a chemical corrector that acts on synaptic transmission, slightly improves the lifetime of $L G I 1^{-1-}$; Lgi1E383A mice but has no effect on the survival of Lgi1 ${ }^{-/-}$mice (Yokoi et al., 2015). This suggests that 4PBA may not be an effective drug for many ADLTE families because heterozygous mutations account for up to $50 \%$ of the cases of this disease (Kalachikov et al., 2002; Senechal et al., 2005; Fukata et al., 2006). Compared with 4PBA, celecoxib has two advantages: (1) it is effective on $L G I 1^{-1-}$ and $L G I 1^{+/-}$mice, implying that it might be effective on at least 34 LGI1 mutations that have been reported (Nobile et al., 2009; Ho et al., 2012); and (2) it is an FDA-approved drug for chronic diseases, indicating that it is more suitable for clinic trials than 4PBA. Unfortunately, with the present protocol, celecoxib did not eliminate the epilepsy in $L G I 1^{-1-}$ mice. Nevertheless, it should be noted that the seizure phenotype is much more severe in $L G I 1^{-/-}$mice than in ADLTE patients, implying that celecoxib may be more effective in patients. It is worth determining whether improved protocols for celecoxib treatment are more effective in eradicating the epilepsy phenotypes of ADLTE patients.

We found that LGI1 deletion results in the dysregulation of $\mathrm{cPLA}_{2}$-Cox2 signaling, providing a new insight onto LGI1 functions in ADLTE. We showed that $\mathrm{CPLA}_{2}$ phosphorylation and Cox 2 activity were enhanced in $L G I 1^{-1-}$ mice before the occurrence of seizures, whereas Cox1 and lipoxygenase were not affected (Fig. 3). Moreover, expressing LGI1 in cultured $L G I 1^{-/-}$neurons reduced the phosphorylation of $\mathrm{CPLA}_{2}$ (Fig. $3 D)$. Previous work has shown that $\mathrm{CPLA}_{2}$ and Cox2 are enriched in punctate intracellular regions (Breder et al., 1995; Pardue et al., 2003), establishing a physical basis for their interactions.

We propose that LGI1 deletion enhances $\mathrm{CPLA}_{2}$-Cox2 signaling and thereby decreases Kv1.2 expression, which was demonstrated by multiple lines of evidence (Figs. 2-4). For example, Cox2 inhibition increased, but AA stimulation attenuated, the expression of Kv1.2 (Fig. 4E). Still, it should be noted that how Cox2 inhibition modulates Kv1.2 expression remains to be determined. We speculate that downstream effectors of Cox2, such as prostaglandin $\mathrm{E}_{2}$ and its receptor EP2, may be involved in Kv1.2 modulation. Indeed, to date, little is known about how Cox 2 signaling modulates membrane channels, although limited studies from cultured smooth muscle cells (Fan et al., 2011) and cerebellar granule cells (He et al., 2013) imply that there may be a synergism or an integration between prostaglandin $\mathrm{E}_{2}$ receptors and voltage-gated channels.

Because Cox2 is increased in the brains of animals and patients experiencing seizures (Yamagata et al., 1993; Serrano et al., 2011; Rojas et al., 2014), many studies have used Cox2 inhibitors to rescue seizures in kindled animals. However, no consensus has been reached. For example, Cox2 inhibitors increase the threshold for PTZ-induced seizures (Akula et al., 2008) and mice treated with them perform better in cognitive tasks (Gobbo and O'Mara, 2004), whereas others have found that Cox2 inhibition or ablation has no effect on the seizures or neuronal survival induced by pilocarpine (Serrano et al., 2011), PTZ (Oliveira et al., 2008; Claycomb et al., 2011), kainic acid (Kunz and Oliw, 2001), or amygdala kindling (Fischborn et al., 2010), and it even intensifies seizures under certain conditions (Baik et al., 1999). We speculate that this controversy may be due to the complex nature of kindled epilepsies, in which multiple factors play roles and Cox 2 may not be the decisive one. ADLTE, however, is an autonomous epilepsy, distinct from kindled epilepsies that are affected by the chemicals used for kindling. This discrepancy may explain why chronic inhibition of Cox2 was sufficient to rescue the seizure phenotypes in $L G I 1^{-1-}$ mice. In addition, discrepant actions of Cox2 inhibitors have been reported. NS398, but not celecoxib, has potent inhibitory effects on ureteral spasms (Lee et al., 2010). In PC12 cells, celecoxib inhibits L-type $\mathrm{Ca}^{2+}$ channels independent of Cox2 (Zhang et al., 2007). Celecoxib also modulates Kv7 currents in different manners in lineage cells (Du et al., 2011). Although these findings suggest a Cox2-independent action of celecoxib, our data argue that celecoxib regulates Kv1.2 by inhibiting Cox2 because Kv1.2 restoration was acquired by NS398 application (Fig. 4).

Celecoxib is prescribed for osteoarthritis, rheumatoid arthritis, pain, inflammatory diseases, and adenomatous polyposis (Lipsky and Isakson, 1997; Steinbach et al., 2000; Crofford, 2002; Edelman et al., 2013; Zeng et al., 2015). In this study, we demonstrated that celecoxib is a promising agent for intervention therapy for ADLTE, as it partly but significantly suppressed epileptogenic activity and extended the lifetime of $L G I 1^{-1-}$ mice. The efficient therapeutic activity in ameliorating seizure susceptibility makes celecoxib a promising long-term treatment to reduce the risk of seizures in family members carrying an LGI1 mutation. Data from clinical trials to evaluate the actions of celecoxib in antiepileptogenic activity is eagerly awaited.

\section{References}

Akula KK, Dhir A, Kulkarni SK (2008) Rofecoxib, a selective cyclooxygenase-2 (COX-2) inhibitor increases pentylenetetrazol seizure threshold in mice: possible involvement of adenosinergic mechanism. Epilepsy Res 78:6070. CrossRef Medline

Baik EJ, Kim EJ, Lee SH, Moon C (1999) Cyclooxygenase-2 selective inhibitors aggravate kainic acid induced seizure and neuronal cell death in the hippocampus. Brain Res 843:118-129. CrossRef Medline

Boillot M, Huneau C, Marsan E, Lehongre K, Navarro V, Ishida S, Dufresnois B, Ozkaynak E, Garrigue J, Miles R, Martin B, Leguern E, Anderson MP, Baulac S (2014) Glutamatergic neuron-targeted loss of LGI1 epilepsy gene results in seizures. Brain 137:2984-2996. CrossRef Medline

Breder CD, Dewitt D, Kraig RP (1995) Characterization of inducible cyclooxygenase in rat brain. J Comp Neurol 355:296-315. CrossRef Medline

Chabrol E, Navarro V, Provenzano G, Cohen I, Dinocourt C, RivaudPéchoux S, Fricker D, Baulac M, Miles R, Leguern E, Baulac S (2010) Electroclinical characterization of epileptic seizures in leucine-rich, gliomainactivated 1-deficient mice. Brain 133:2749-2762. CrossRef Medline

Claycomb RJ, Hewett SJ, Hewett JA (2011) Prophylactic, prandial rofecoxib treatment lacks efficacy against acute PTZ-induced seizure generation and kindling acquisition. Epilepsia 52:273-283. CrossRef Medline

Crofford LJ (2002) Specific cyclooxygenase-2 inhibitors: what have we learned since they came into widespread clinical use? Curr Opin Rheumatol 14:225-230. CrossRef Medline

Das A, Wallace GC 4th, Holmes C, McDowell ML, Smith JA, Marshall JD, Bonilha L, Edwards JC, Glazier SS, Ray SK, Banik NL (2012) Hippocampal tissue of patients with refractory temporal lobe epilepsy is associated with astrocyte activation, inflammation, and altered expression of channels and receptors. Neuroscience 220:237-246. CrossRef Medline 
Dodson PD, Barker MC, Forsythe ID (2002) Two heteromeric Kv1 potassium channels differentially regulate action potential firing. J Neurosci 22:6953-6961. Medline

Du XN, Zhang X, Qi JL, An HL, Li JW, Wan YM, Fu Y, Gao HX, Gao ZB, Zhan Y, Zhang HL (2011) Characteristics and molecular basis of celecoxib modulation on K(v)7 potassium channels. Br J Pharmacol 164:17221737. CrossRef Medline

Edelman AB, Jensen JT, Doom C, Hennebold JD (2013) Impact of the prostaglandin synthase-2 inhibitor celecoxib on ovulation and luteal events in women. Contraception 87:352-357. CrossRef Medline

Fan F, Ma A, Guan Y, Huo J, Hu Z, Tian H, Chen L, Zhu S, Fan L (2011) Effect of $\mathrm{PGE}_{2}$ on DA tone by EP4 modulating Kv channels with different oxygen tension between preterm and term. Int J Cardiol 147:58-65. CrossRef Medline

Farooqui AA, Yang HC, Rosenberger TA, Horrocks LA (1997) Phospholipase A2 and its role in brain tissue. J Neurochem 69:889-901. CrossRef Medline

Ferraro TN, Golden GT, Smith GG, St Jean P, Schork NJ, Mulholland N, Ballas C, Schill J, Buono RJ, Berrettini WH (1999) Mapping loci for pentylenetetrazol-induced seizure susceptibility in mice. J Neurosci 19: 6733-6739. Medline

Fischborn SV, Soerensen J, Potschka H (2010) Targeting the prostaglandin E2 EP1 receptor and cyclooxygenase-2 in the amygdala kindling model in mice. Epilepsy Res 91:57-65. CrossRef Medline

Franklin KBJ, Paxinos G (2001) The mouse brain in stereotaxic coordinates, Ed 2. San Diego, CA: Academic.

Fukata Y, Adesnik H, Iwanaga T, Bredt DS, Nicoll RA, Fukata M (2006) Epilepsy-related ligand/receptor complex LGI1 and ADAM22 regulate synaptic transmission. Science 313:1792-1795. CrossRef Medline

Fukata Y, Lovero KL, Iwanaga T, Watanabe A, Yokoi N, Tabuchi K, Shigemoto R, Nicoll RA, Fukata M (2010) Disruption of LGI1-linked synaptic complex causes abnormal synaptic transmission and epilepsy. Proc Natl Acad Sci U S A 107:3799-3804. CrossRef Medline

Gasselin C, Inglebert Y, Debanne D (2015) Homeostatic regulation of $\mathrm{h}$-conductance controls intrinsic excitability and stabilizes the threshold for synaptic modification in CAl neurons. J Physiol 593:4855-4869. CrossRef Medline

Gobbo OL, O'Mara SM (2004) Post-treatment, but not pre-treatment, with the selective cyclooxygenase-2 inhibitor celecoxib markedly enhances functional recovery from kainic acid-induced neurodegeneration. Neuroscience 125:317-327. CrossRef Medline

Guan D, Lee JC, Tkatch T, Surmeier DJ, Armstrong WE, Foehring RC (2006) Expression and biophysical properties of Kvl channels in supragranular neocortical pyramidal neurones. J Physiol 571:371-389. CrossRef Medline

Haglund MM, Hochman DW (2005) Furosemide and mannitol suppression of epileptic activity in the human brain. J Neurophysiol 94:907-918. CrossRef Medline

He YL, Liu DD, Fang YJ, Zhan XQ, Yao JJ, Mei YA (2013) Exposure to extremely low-frequency electromagnetic fields modulates $\mathrm{Na}^{+}$currents in rat cerebellar granule cells through increase of $\mathrm{AA} / \mathrm{PGE}_{2}$ and $\mathrm{EP}$ receptor-mediated cAMP/PKA pathway. PLoS One 8:e54376. CrossRef Medline

Hille B (2001) Ionic channels of excitable membranes. Sunderland, MA: Sinauer.

Ho YY, Ionita-Laza I, Ottman R (2012) Domain-dependent clustering and genotype-phenotype analysis of LGI1 mutations in ADPEAF. Neurology 78:563-568. CrossRef Medline

Huitema BE (2011) The analysis of covariance and alternatives: statistical methods for experiments, quasi-experiments. Hoboken, NJ: Wiley.

Kalachikov S, Evgrafov O, Ross B, Winawer M, Barker-Cummings C, Martinelli Boneschi F, Choi C, Morozov P, Das K, Teplitskaya E, Yu A, Cayanis E, Penchaszadeh G, Kottmann AH, Pedley TA, Hauser WA, Ottman R, Gilliam TC (2002) Mutations in LGIl cause autosomal-dominant partial epilepsy with auditory features. Nat Genet 30:335-341. CrossRef Medline

Kleinbaum DG, Kupper LL, Nizam A, Muller KE (2007) Applied regression analysis and other multivariable methods. Boston, MA: Cengage Learning.

Kole MH, Letzkus JJ, Stuart GJ (2007) Axon initial segment Kv1 channels control axonal action potential waveform and synaptic efficacy. Neuron 55:633-647. CrossRef Medline
Kunz T, Oliw EH (2001) Nimesulide aggravates kainic acid-induced seizures in the rat. Pharmacol Toxicol 88:271-276. CrossRef Medline

Lee SY, Lee MY, Park SH, Kim TH, Moon YT, Han JH, Myung SC (2010) NS-398 (a selective cyclooxygenase-2 inhibitor) decreases agonistinduced contraction of the human ureter via calcium channel inhibition. J Endourol 24:1863-1868. CrossRef Medline

Li KX, Lu YM, Xu ZH, Zhang J, Zhu JM, Zhang JM, Cao SX, Chen XJ, Chen Z, Luo JH, Duan S, Li XM (2011) Neuregulin 1 regulates excitability of fast-spiking neurons through Kv1.1 and acts in epilepsy. Nat Neurosci 15:267-273. CrossRef Medline

Lipsky PE, Isakson PC (1997) Outcome of specific COX-2 inhibition in rheumatoid arthritis. J Rheumatol Suppl 49:9-14. Medline

Marcheselli VL, Bazan NG (1996) Sustained induction of prostaglandin endoperoxide synthase- 2 by seizures in hippocampus. inhibition by a platelet-activating factor antagonist. J Biol Chem 271:24794-24799. CrossRef Medline

Michelucci R, Poza JJ, Sofia V, de Feo MR, Binelli S, Bisulli F, Scudellaro E, Simionati B, Zimbello R, D’Orsi G, Passarelli D, Avoni P, Avanzini G, Tinuper P, Biondi R, Valle G, Mautner VF, Stephani U, Tassinari CA, Moschonas NK, et al. (2003) Autosomal dominant lateral temporal epilepsy: clinical spectrum, new epitempin mutations, and genetic heterogeneity in seven European families. Epilepsia 44:1289-1297. CrossRef Medline

Michelucci R, Mecarelli O, Bovo G, Bisulli F, Testoni S, Striano P, Striano S, Tinuper P, Nobile C (2007) A de novo LGI1mutation causing idiopathic partial epilepsy with telephone-induced seizures. Neurology 68:21502151. CrossRef Medline

Michelucci R, Pasini E, Nobile C (2009) Lateral temporal lobe epilepsies: clinical and genetic features. Epilepsia 50:S52-S54. CrossRef Medline

Naraba H, Murakami M, Matsumoto H, Shimbara S, Ueno A, Kudo I, Oh-ishi S (1998) Segregated coupling of phospholipases A2, cyclooxygenases, and terminal prostanoid synthases in different phases of prostanoid biosynthesis in rat peritoneal macrophages. J Immunol 160:2974-2982. Medline

Nobile C, Michelucci R, Andreazza S, Pasini E, Tosatto SC, Striano P (2009) LGI1 mutations in autosomal dominant and sporadic lateral temporal epilepsy. Hum Mutat 30:530-536. CrossRef Medline

O’Banion MK (1999) Cyclooxygenase-2: molecular biology, pharmacology, and neurobiology. Crit Rev Neurobiol 13:45-82. CrossRef Medline

Ohkawa T, Fukata Y, Yamasaki M, Miyazaki T, Yokoi N, Takashima H, Watanabe M, Watanabe O, Fukata M (2013) Autoantibodies to epilepsyrelated LGI1 in limbic encephalitis neutralize LGI1-ADAM22 interaction and reduce synaptic AMPA receptors. J Neurosci 3:18161-18174. CrossRef Medline

Oliveira MS, Furian AF, Royes LF, Fighera MR, Fiorenza NG, Castelli M, Machado P, Bohrer D, Veiga M, Ferreira J, Cavalheiro EA, Mello CF (2008) Cyclooxygenase-2/PGE 2 pathway facilitates pentylenetetrazolinduced seizures. Epilepsy Res 79:14-21. CrossRef Medline

Ottman R, Risch N, Hauser WA, Pedley TA, Lee JH, Barker-Cummings C, Lustenberger A, Nagle KJ, Lee KS, Scheuer ML (1995) Localization of a gene for partial epilepsy to chromosome 10q. Nat Genet 10:56-60. CrossRef Medline

Pallant J (2013) SPSS survival manual: a step by step guide to data analysis using IBM SPSS. Maidenhead, UK: Open UP.

Pardue S, Rapoport SI, Bosetti F (2003) Co-localization of cytosolic phospholipase A(2) and cyclooxygenase-2 in rhesus monkey cerebellum. Brain Res Mol Brain Res 116:106-114. CrossRef Medline

Rice JA (2006) Mathematical statistics and data analysis. Belmont, CA: Duxbury.

Rojas A, Jiang J, Ganesh T, Yang MS, Lelutiu N, Gueorguieva P, Dingledine R (2014) Cyclooxygenase-2 in epilepsy. Epilepsia 55:17-25. CrossRef Medline

Schulte U, Thumfart JO, Klöcker N, Sailer CA, Bildl W, Biniossek M, Dehn D, Deller T, Eble S, Abbass K, Wangler T, Knaus HG, Fakler B (2006) The epilepsy-linked Lgil protein assembles into presynaptic Kv1 channels and inhibits inactivation by Kvbetal. Neuron 49:697-706. CrossRef Medline

Scott KF, Bryant KJ, Bidgood MJ (1999) Functional coupling and differential regulation of the phospholipase A2-cyclooxygenase pathways in inflammation. J Leukoc Biol 66:535-541. CrossRef Medline

Seagar M, Russier M, Caillard O, Maulet Y, Fronzaroli-Molinieres L, De San Feliciano M, Boumedine-Guignon N, Rodriguez L, Zbili M, Usseglio F, Formisano-Tréziny C, Youssouf F, Sangiardi M, Boillot M, Baulac S, Benitez MJ, Garrido JJ, Debanne D, El Far O (2017) LGI1 tunes intrinsic 
excitability by regulating the density of axonal Kv1 channels. Proc Natl Acad Sci U S A 114:7719-7724. CrossRef Medline

Senechal KR, Thaller C, Noebels JL (2005) ADPEAF mutations reduce levels of secreted LGI1, a putative tumor suppressor protein linked to epilepsy. Hum Mol Genet 14:1613-1620. CrossRef Medline

Serrano GE, Lelutiu N, Rojas A, Cochi S, Shaw R, Makinson CD, Wang D, FitzGerald GA, Dingledine R (2011) Ablation of cyclooxygenase-2 in forebrain neurons is neuroprotective and dampens brain inflammation after status epilepticus. J Neurosci 31:14850-14860. CrossRef Medline

Silva J, Sharma S, Cowell JK (2015) Homozygous deletion of the LGI1 gene in mice leads to developmental abnormalities resulting in cortical dysplasia. Brain Pathol 25:587-597. CrossRef Medline

Steinbach G, Lynch PM, Phillips RK, Wallace MH, Hawk E, Gordon GB, Wakabayashi N, Saunders B, Shen Y, Fujimura T, Su LK, Levin B, Godio L, Patterson S, Rodriguez-Bigas MA, Jester SL, King KL, Schumacher M, Abbruzzese J, DuBois RN, et al. (2000) The effect of celecoxib, a cyclooxygenase-2 inhibitor, in familial adenomatous polyposis. $\mathrm{N}$ Engl J Med 342:1946-1952. CrossRef Medline

Takano T, Panesar M, Papillon J, Cybulsky AV (2000) Cyclooxygenases-1 and 2 couple to cytosolic but not group IIA phospholipase A2 in COS-1 cells. Prostaglandins Other Lipid Mediat 60:15-26. CrossRef Medline

Thomas R, Favell K, Morante-Redolat J, Pool M, Kent C, Wright M, Daignault K, Ferraro GB, Montcalm S, Durocher Y, Fournier A, Perez-Tur J, Barker PA (2010) LGI1 is a nogo receptor 1 ligand that antagonizes myelinbased growth inhibition. J Neurosci 30:6607-6612. CrossRef Medline

Wang YN, Zhou L, Li YH, Wang Z, Li YC, Zhang YW, Wang Y, Liu G, Shen Y (2015) Protein interacting with C-kinase 1 deficiency impairs glutathione synthesis and increases oxidative stress via reduction of surface excitatory amino acid carrier 1. J Neurosci 35:6429-6443. CrossRef Medline

Wang Y, Xu C, Xu Z, Ji C, Liang J, Wang Y, Chen B, Xu X, Gao F, Wang S, Guo Y, Li X, Luo J, Duan S, Chen Z (2017) Depolarized GABAergic signaling in subicular microcircuits mediates generalized seizure in temporal lobe epilepsy. Neuron 95:1-14. CrossRef Medline

Wen L, Lu YS, Zhu XH, Li XM, Woo RS, Chen YJ, Yin DM, Lai C, Terry AV Jr, Vazdarjanova A, Xiong WC, Mei L (2010) Neuregulin 1 regulates pyramidal neuron activity via ErbB4 in parvalbumin-positive interneurons. Proc Natl Acad Sci U S A 107:1211-1216. CrossRef Medline
Xie YJ, Zhou L, Jiang N, Zhang N, Zou N, Zhou L, Wang Y, Cowell JK, Shen Y (2015) Essential roles of leucine-rich glioma inactivated 1 in the development of embryonic and postnatal cerebellum. Sci Rep 5:7827. CrossRef Medline

Yamagata K, Andreasson KI, Kaufmann WE, Barnes CA, Worley PF (1993) Expression of a mitogen-inducible cyclooxygenase in brain neurons: regulation by synaptic activity and glucocorticoids. Neuron 11:371-386. CrossRef Medline

Yokoi N, Fukata Y, Kase D, Miyazaki T, Jaegle M, Ohkawa T, Takahashi N, Iwanari $\mathrm{H}$, Mochizuki Y, Hamakubo T, Imoto K, Meijer D, Watanabe M, Fukata M (2015) Chemical corrector treatment ameliorates increased seizure susceptibility in a mouse model of familial epilepsy. Nat Med 21:19-26. CrossRef Medline

Yu YE, Wen L, Silva J, Li Z, Head K, Sossey-Alaoui K, Pao A, Mei L, Cowell JK (2010) Lgil null mutant mice exhibit myoclonic seizures and CA1 neuronal hyperexcitability. Hum Mol Genet 19:1702-1711. CrossRef Medline

Zeng C, Wei J, Li H, Yang T, Gao SG, Li YS, Xiong YL, Xiao WF, Luo W, Yang TB, Lei GH (2015) Comparison between $200 \mathrm{mg}$ QD and $100 \mathrm{mg}$ BID oral celecoxib in the treatment of knee or hip osteoarthritis. Sci Rep 5:10593. CrossRef Medline

Zhang Y, Tao J, Huang H, Ding G, Cheng Y, Sun W (2007) Effects of celecoxib on voltage-gated calcium channel currents in rat pheochromocytoma (PC12) cells. Pharmacol Res 56:267-274. CrossRef Medline

Zhou JH, Wang XT, Zhou L, Zhou L, Xu FX, Su LD, Wang H, Jia F, Xu FQ, Chen GQ, De Zeeuw CI, Shen Y (2017) Ablation of TFR1 in Purkinje cells inhibits mGlul trafficking and impairs motor coordination, but not autistic-like behaviors. J Neurosci 37:11335-11352. CrossRef Medline

Zhou L, Yang D, Wang DJ, Xie YJ, Zhou JH, Zhou L, Huang H, Han S, Shao CY, Li HS, Zhu JJ, Qiu MS, De Zeeuw CI, Shen Y (2015) Numb deficiency in cerebellar Purkinje cells impairs synaptic expression of metabotropic glutamate receptor and motor coordination. Proc Natl Acad Sci U S A 112:15474-15479. CrossRef Medline

Zhou YD, Lee S, Jin Z, Wright M, Smith SE, Anderson MP (2009) Arrested maturation of excitatory synapses in autosomal dominant lateral temporal lobe epilepsy. Nat Med 15:1208-1214. CrossRef Medline 